\title{
Real and Monetary Challenges to Wage Policy in Germany at the Turn of the Millennium: Technical Progress, Globalization and European Monetary Union
}

\author{
Wolfgang Franz
}

Content

1 Introduction

2 The Influence of Globalization and Skill-Biased Technical Progress on Wages across Skill Groups in Germany

\subsection{Some Stylized Facts}

2.2 International Trade

2.2.1 Factor Content Analysis

2.2.2 Price Effects Analysis

2.2.3 Empirical Findings

\subsection{Skill-Biased Technical Progress}

2.4 Summary and Implications

3 Labor Market Effects of EMU

4 Conclusion

JEL-Classifications: J21, J31, F16, O33, F33

Keywords: Wages, Wage Structure, Skill-Biased Technological Change, International Trade, European Monetary Union

Address: Zentrum für Europäische Wirtschaftsforschung (ZEW)

P.O. Box 103443

68034 Mannheim, Germany

Tel.: $\quad 0621-1235-100$

Fax: $\quad 0621-1235-222$

e-mail: franz@zew.de

\footnotetext{
1 Paper presented at the Summer Workshop of the Centre for European Economic Research (ZEW), Mannheim, on "Labor and Industrial Economics", June 9, 1999, and the CESifo-Symposium on "European Labor Market Issues", Munich, June 22, 1999. I am grateful for helpful comments by Bernd Fitzenberger (Dresden) and Matthias Lücke (Kiel) without implicating them.
} 


\begin{abstract}
At the turn of the millennium three frequently cited potential causes of new challenges for wage policy in Germany are revisited in this study: skilled-biased technological progress, the increasing international integration of labor and product markets, and the monetary integration of the EMU. While there is now a fairly broad consensus on the basic facts about the development of wages and employment across skill groups, there is considerable disagreement to explain these trends, in particular to what extent skill-biased technical change and trade liberalization share a major responsibility. The conclusion of this paper is that both factors are at work with a slight emphasis on the first candidate. Moreover, while EMU in our opinion does not represent the major threat for wage policy, it is the Single Market which requires wage policy to be on the lookout and to meet those challenges.
\end{abstract}




\section{Non-technical Summary}

At the turn of the millennium, wage policy in Germany has to face old and new challenges. Old challenges require wage moderation and a more flexible wage structure in order to contribute to a successful fight against persistently high levels of unemployment. Three leading potential causes of new challenges are reviewed in this study. These are skilledbiased technical progress, the increasing international integration of labor and product markets, and the monetary integration of the EMU. For all three cases, pertinent evidence was obtained by inspection of the past, but there are no signs that technological change and globalization will be confined to this century or even decade. The same argument holds for labor market effects of EMU.

With respect to trade liberalization and technological change, the sequence of the aspects on which the literature agrees or disagrees comes as a surprise. There is now a fairly broad consensus on the basic facts about the development of wages and employment across skill groups, despite unresolved methodological differences. How to explain these trends is subject to considerable disagreement, in particular to what extent trade liberalization and skill-biased technical change share a major responsibility. Remarkably, however, the consensus is again on policy implications. Virtually no study favors protection against imports from developing countries, or against a skill-biased technical progress, but most agree on sufficient wage flexibility, better education and training, and some type of income redistribution.

What does this mean for future wage policy in Germany? Being still at the beginning of EMU the answer is relatively simple. While EMU in our opinion does not represent a major threat for wage policy, it should be on the lookout for possible country-specific shocks which are not extremely likely but cannot be ruled out for the future. Moreover, wage policy in Germany has to carefully watch wage policies in other (EMU) countries in order to remain competitive. From this viewpoint, a Europeanization of wage policy is inadequate. 


\section{Introduction}

The longstanding inability, if not unwillingness, of economic policy, and particularly wage policy to successfully combat high and persistent unemployment is already a burden serious enough for the German labor market. Now, however, additional challenges have arisen which cloud the perspectives for unemployment to return to normal levels in Germany and in other countries. To some extent all these problems are old friends. The desperate situation of the Silesian linen weavers in the last century and the present unemployment of low skilled workers possibly resulting from a skill biased technical progress constitute similar phenomena. Another example is the fear of adverse employment effects of trade liberalization expressed by opponents of the German "Zollverein" (tarif agreement) in 1834 and the current proposals to protect e.g. wages and social standards within globalized markets against a race to the bottom in order to avoid our wages to be set in Bejing. ${ }^{1}$ Moreover, a monetary union is anything but an invention of this century's nineties.

Instead of viewing these challenges in the 1990's as the reign of terror by economics and of looking at them like a rabbit vis-à-vis a snake, there are several possibilities to meet them, such as upgrading of skills, higher mobility, and wage policy. This paper deals with wages and wage structures. It goes without saying, however, that neither does wage policy bear the sole responsibility for joblessness, nor is wage policy a panacea to solve labor market problems in Germany. On the other hand, wages and wage structures play an important role which justifies the focus of this paper on them. This holds in two causality directions: Wages are influenced by technical progress and "globalization" - the increasing international integration of markets for goods, factors, and technology - and their flexibility codetermines the employment effects of these factors. What do we know and not know about these aspects and what are likely consequences for wage setting rules in Germany? To offer an assessment of these topics, both on theoretical and empirical grounds, is the purpose of this paper.

\section{The Influence of Globalization and Skill-Biased Technical Progress on Wages across Skill Groups in Germany}

International trade as well as technical progress are powerful driving forces of an increasing welfare. But this does not necessarily mean that virtually everyone gains from them. Cheap

\footnotetext{
${ }^{1}$ This is the title of a paper by Freeman (1995).
} 
imports of goods from emerging countries ${ }^{2}$ or migrant workers from low-wage economies are said to hurt unskilled labor in Germany. In the latter case the policy response in Germany was to enact a law which forces firms in the construction industry to pay German wages to foreign EU-workers and to declare the negotiated low-wage generally binding for all construction workers. ${ }^{3}$

Skill-biased technological change is assessed as another important culprit for the observed declining employment prospects of low-skilled labor. The rapid diffusion of information technologies and the adoption of new forms of work organisation is supposed to bias labor demand to the disadvantage of low-skilled workers.

The distinction between the impact of trade and technology on wages and employment does not only imply that both should be viewed as separate factors. There are clear interrelationships; for example the possibility of a stronger international competition causing an increasing pressure to adopt quickly new technologies. Technological progress, on the other hand, may support the expansion of international trade. ${ }^{4}$

\subsection{Some Stylized Facts}

This section is devoted to providing an empirical background for the following discussions by establishing some facts about the development both of the skill structure of the workforce and of wages across skill groups.

Table 1 displays the skill structure of the entire labor force, all employees, and full-time working German males aged 18 to 65 years. The data refer to West Germany allowing for an examination of long-term trends not clouded by differences of educational systems between East and West Germany. Since labor force participation rates as well as the composition of employment with respect to gender, nationality, and number of working hours has changed dramatically, the last group in table 1 represents the more homogenous population compared to the others. Whatever measure is used, the work force of Germany has become considerably more skilled which was also observed in other countries. ${ }^{5}$ By and large, the fraction of unskilled workers was nearly halved, whereas the corresponding figure for high-skilled labor is now twice as high as in 1975. Referring to 1995, the fraction of

\footnotetext{
${ }^{2}$ Emerging economies may be thought of, for example, Brazil, China, India, Indonesia, Korea, Malaysia, Thailand.

${ }^{3}$ See Leiner and Vosgerau (1998) for a theoretical analysis of this law ("Arbeitnehmer-Entsendegesetz").

${ }^{4}$ See Acemoglu (1999) and OECD (1997), p. 93.

${ }^{5}$ See e.g. Johnson (1997) for the U.S..
} 
unskilled workers is higher in the labor force compared to total employment due to the higher unemployment rates of unskilled workers. This effect was less pronounced in 1975 . Moreover, the percentage of unskilled workers decreased in the last group of table 1, which can be attributed either to the fact that the fraction of unskilled foreign workers is higher than that of German unskilled workers and/or that unskilled workers have less often fulltime jobs than skilled workers. On the other hand, the fraction of high-skilled labor in the group of German full-time workers is also lower (but roughly identical in the remaining groups). This observation can be explained by the higher percentage of high-skilled females working part-time. However, not too much emphasis should be put on the accuracy of these figures since they are based on different data sets.

Hence, by any measure the German workforce has become more skilled. What are the likely consequences of an increasing supply of skilled workers on their wages? At first glance the answer seems clear. Given a downward-sloped demand-curve for skilled workers the shift of the supply-curve should result in a decline of wages for high-skilled workers relative to medium-skilled workers. Is this hypothesis consistent with the facts on the wage structure across skill groups? In order to shed light on this aspect, an inspection of (the development of) the wage structure across skill groups in Germany is in order which translated directly into the actual discussion in the public on wages and the wages structures not flexible enough to meet challenges to the German labor market. In particular, for the past decades, the broad-brush view of the German wage structure considers West Germany as a highwage economy with a fairly compressed wage structure which has even continued to become more compressed [OECD (1997)]. Though not entirely wrong this may be too broad a brush.

More specifically, figure 1 displays estimated time trends of real wages for full-time male workers in West Germany covering the time period from 1975 to 1990 . Before discussing the trends, some remarks about the data are in order. ${ }^{6}$

The data source is a one percent random sample of employees who are subject to social security contributions provided by the "Institut für Arbeitsmarkt- und Berufsforschung" (IAB) of the Federal Labor Office. Wages in this dataset are censored from above due to the threshold levels in social security contributions. The structural break in wages between 1983 and 1984 is corrected for. Workers are grouped by their skills defined according to formal education levels such as

\footnotetext{
${ }^{6}$ The following considerations are based on Fitzenberger and Franz (1998). See also Fitzenberger (1999a,b).
} 
Table 1: Skill Composition of the Labor Force in West Germany 1975 and 1995 (Percentages) $^{\text {a) }}$

\begin{tabular}{|c|c|c|c|}
\hline Year & Unskilled & $\begin{array}{l}\text { Medium- } \\
\text { Skilled }\end{array}$ & $\begin{array}{l}\text { High- } \\
\text { Skilled }\end{array}$ \\
\hline & \multicolumn{3}{|c|}{ Labor Force } \\
\hline \multirow{3}{*}{$\begin{array}{l}1975 \\
1995\end{array}$} & 37.4 & 49.2 & 7.0 \\
\hline & 19.0 & 59.0 & 13.7 \\
\hline & \multicolumn{3}{|c|}{ Total Employment } \\
\hline \multirow{3}{*}{$\begin{array}{l}1975 \\
1995\end{array}$} & 36.7 & 49.9 & 7.1 \\
\hline & 16.6 & 60.2 & 14.4 \\
\hline & \multicolumn{3}{|c|}{$\begin{array}{l}\text { Full-Time Working } \\
\text { German Males Aged } \\
18 \text { to } 65\end{array}$} \\
\hline 1975 & 20.2 & 66.3 & 4.6 \\
\hline 1995 & 12.3 & 68.3 & 10.2 \\
\hline
\end{tabular}

a) Some individual skill-groups were omitted and some imprecision is due to rounding, hence, figures do not add up to 100 percent.

Unskilled: $\quad$ no or unknown vocational training

Medium-Skilled: apprenticeship training completed

High-Skilled: $\quad$ university degree and degree of advanced college for higher education (Fachhochschule)

Sources: - Labor force and total employment: Bundesministerium für Bildung, Wissenschaft, Forschung und Technologie (1997), Grund- und Strukturdaten 1997/98, Bonn; calculations by the author.

- Full-Time Workers: Möller (1999). 
Figure 1: Estimated Time Trends of Real Wages of Full-Time Working Males in the Manufacturing Sector of West Germany $(1975=0)^{a)}$
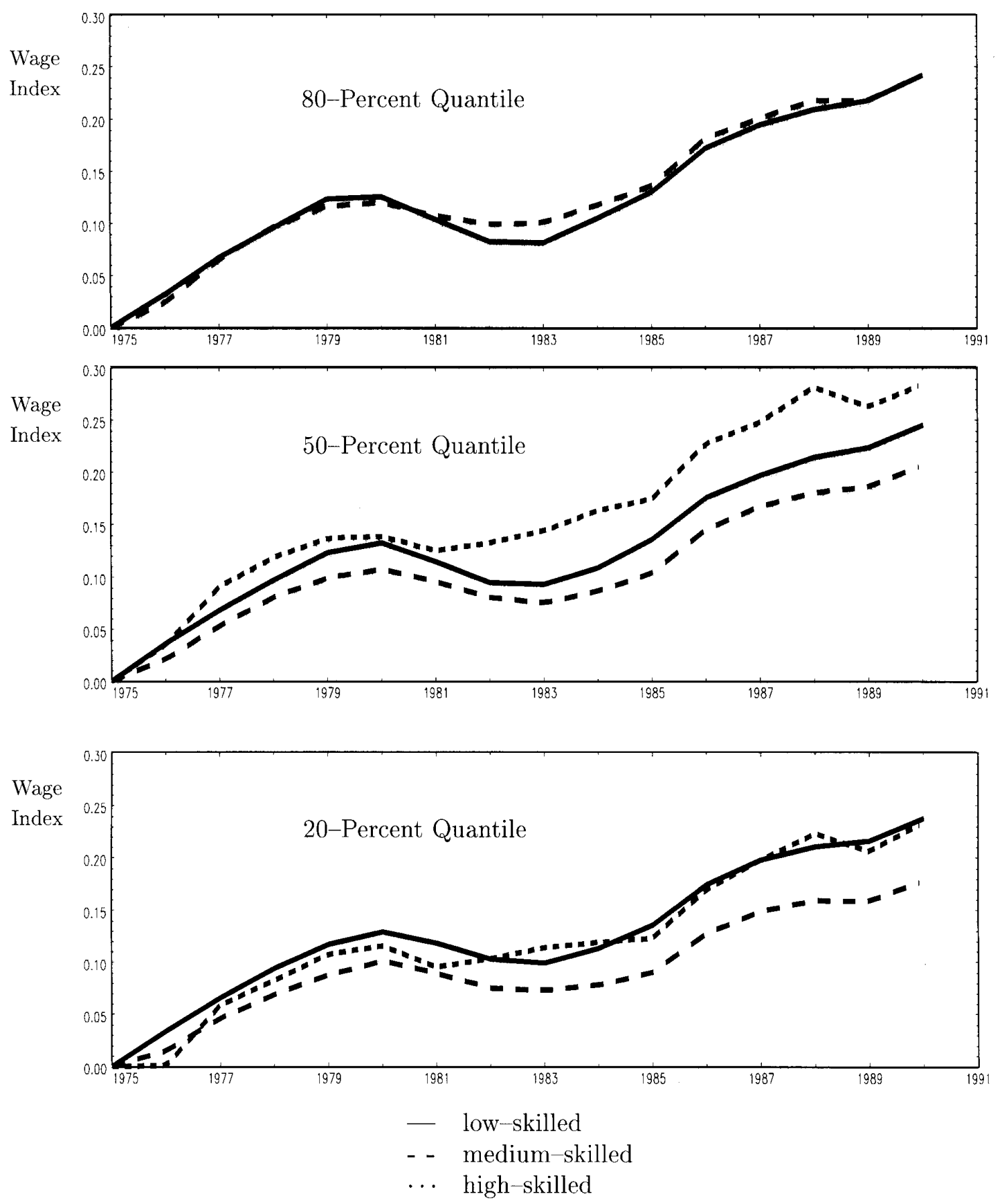

a) See text for details.

Source: Fitzenberger and Franz (1998). 
- low-skilled (U): without a vocational training degree,

- medium-skilled (M): with a vocational training degree,

- high-skilled $(\mathrm{H})$ : with a university or technical college degree.

In order to highlight developments of the wage structure within and between skill groups, figure 1 shows the 80 percent-, 50 percent- and 20 percent quantiles, i.e. for the 80 percent quantile, that level of real wages which exactly 80 percent of all workers (in the skill group under consideration) receive at most and 20 percent at least. Due to the aforementioned censoring the 80 percent quantile cannot be estimated reliably. The estimation of the time trends in the quantiles is carried out by using censored quantile regressions for log wages which include a quadratic age polynom, sectoral dummies and time dummies for 1976 to $1990 .^{7}$ While a distinction is made between the manufacturing and the non-manufacturing sector, figure 1 depicts results for the manufacturing sector only. Finally, all figures are expressed as indices with $1975=0$.

As can be seen the development of wages differs in the three five-years periods. Between 1975 and 1980 there was an increase of real wages over all skill groups and quantiles between 8 and 12 percent. Real wages remained fairly stable between 1980 and 1985 (in some cases they even declined). The time period 1985 to 1990, however, is characterized again by an increase of real wages by roughly the same order of magnitude as during the time period 1975 to 1980 . Other differences concern skill groups and quantiles. While low and medium skilled workers have similar wage increases in the 80 percent quantile, wages in the 20 and 50 percent quantiles display quite different developments because wage growth for low and high skilled workers was higher compared to that of medium skilled workers. Put differently, in these quantiles we observed a U-shaped pattern across skill groups, i.e., between group wage dispersion at these quantiles increased between $M$ and $H$ and decreased between $U$ and $M$. This holds for both manufacturing and for nonmanufacturing sectors. However, focusing exclusively on low skilled workers we observe similar wage trends in all quantiles, i.e., the wage dispersion within this group remains fairly unchanged over time. In contrast, for $M$ and $H$ one observes increasing wage inequality within these groups, since wage growth is higher at higher quantiles. Taken together, while wage inequality for full-time working males increases in the time period under consideration, this rise in inequality differs within and between skill groups.

\footnotetext{
${ }^{7}$ See Fitzenberger and Franz (1998) for details.
} 
The trends for full-time working females (not depicted in figure 1) are somewhat different. As is shown by Fitzenberger (1999a) wage dispersion across skill groups and also within skill groups in the lower part of the wage distribution decreases strongly from 1975 to 1990. On the other side, the wage dispersion for medium-skilled females above the median tends to increase substantially.

Summing up, the notion of the German wage structure as being fairly compressed and even tending to become more compressed over time is only partly correct. It obscures important differences between male and female workers, skill groups and wage groups. The more important conclusion is, however, that despite an increased supply of high-skilled workers their relative wages did not decline. Hence, demand shifts must have had occurred. Two candidates emerge in the literature and are discussed in what follows, namely globalization and skill-biased technological progress.

\subsection{International Trade}

The argument that international trade affects the domestic wage structure to the disadvantage of low skilled workers is based on conventional trade theories and takes into account several empirical facts. One of the facts is the increased openess of markets due to freer trade and the improvement of the skills of the workforce especially in many developed countries. The expansion of trade - which is due to, say, reduced trade barriers as a consequence of various GATT agreements - between skilled-labor-abundant developed economies and unskilled-labor-abundant developing countries will tend to change the structure of production. Developed countries increase their production and exports of commodities that use skilled labor intensively and their import demand for goods requiring low skilled labor. The opposite holds for emerging countries as long as the major share of their workforce remains (still) low skilled. In developed countries on their path to equilibrium, the relative prices of unskilled-labor-intensive products imported from lowwage countries will decline and, in turn, this will cause a more-than-proportional cut in the wage of unskilled labor in relation to skilled-labor in advanced economies (StolperSamuelson theorem). In developing countries relative wages of skilled workers tend to decrease whereas low-wage earners tend to experience an improvement of their relative pay. According to the conventional Heckscher-Ohlin-Samuelson (HOS) model in equilibrium, under specific circumstances factor prices are equalized throughout the world. More 
specifically, the less skilled worker in Germany is paid the same as his fellow worker in India.

While these conventional trade theories have to be modified in order to accommodate some stylized facts such as rigid wages, it goes without saying that the relevant question is not whether international trade affects wages of low skilled workers at all. Obviously, when Germany imports trainers produced by low paid Indian labor, workers in a German factory producing shoes at wages ten times those of the worker in New Delhi will soon find themselves on the dole. The relevant question in this context is whether German low wages are fully set in Delhi rather than by domestic forces, too. ${ }^{8}$

A precondition for German wages to be set in Delhi is that international competition leads to a decrease of German producer prices of goods which intensively incorporate low-skilled labor. Several arguments cast doubts, however, whether, as a consequence, full factor price equalization is to be expected in the (near) future. First, the theoretical model rests on a set of highly unrealistic assumptions such as identical technology and tastes, absence of costs of trade and scale effects, and the like. These caveats are commonplace in nearly all textbooks on international trade. ${ }^{9}$ Second, factor price equalization concerns, at least in the first round, those sectors producing tradable goods. The more workplaces for unskilled labor are available in the nontraded goods sector, the more likely it is that wages at the bottom are determined mainly by domestic forces. Third, in Germany there are persistent regional differences between wages of the same quality of labor and a huge body of econometric wage equations arrive at the conclusion that regional forces heavily affect wages.

In order to determine empirically the size of the effects of trade on changes in developedcountry markets basically two methods are employed in the literature, namely factor content analysis and price effects models. Factor content studies are favored by most labor economists and some trade economists whereas other trade economists emphasize price effects models. But as has been pointed out by Freeman (1995) "the techniques are more complementary than opposite" (p. 16).

\footnotetext{
8 See Freeman (1995), OECD (1997), chapter 4, and the "Policy Forum: Trade and Labour Market Adjustment" in the Economic Journal 108 (September 1998) for useful surveys. See also Black (1998) and Sauernheimer (1996).

${ }^{9}$ Haberler (1961) notes about the assumptions underlying the theory of factor price equalization: "These assumptions ... are so restrictive and so unrepresentative of actual reality that the theory can be said to prove the opposite of what it seems to purport to say ..." (p. 18).
} 


\subsubsection{Factor Content Analysis}

The idea of factor content studies is to calculate the "effective" factor endowment of an economy. Effective factor endowment differs from actual factor endowment due to labor input in exported and imported goods. More specifically, foreign labor input in imported goods is added to domestic labor supply, whereas domestic labor input in exported goods is subtracted from domestic labor supply. The balance of both corrections then gives an estimate of the impact of international trade on labor supply. On the basis of estimated elasticities of a changing labor demand on wages it is then calculated to what extent international trade affects domestic wages. For the purpose under consideration, the input of low skilled labor in imported goods is added to the domestic low skilled work force and the resulting shift of low skilled labor supply is then transformed into a pressure on the wages of low skilled workers.

In order to obtain reliable estimates, however, several modifications of this procedure are necessary. To some extent, some studies fail to make these corrections, and this gives rise to criticism of factor content analysis.

(i) The impact of trade on labor demand is typically estimated for given wages. In the absence of nominal wage rigidities it is possible, however, that wage adjustments occur in sectors that are competing with imported goods. If this is the case, the calculated shift of effective labor demand underestimates the true pressure on wages because a possible feedback from decreasing domestic wages of low skilled labor, which arguably increases domestic ability to compete with imports, is neglected. Given the inflexibility of wages especially at the lower end of the wage structure in Germany, the omission of this feedback may not bias estimated effects too seriously.

(ii) Another feedback which is frequently neglected concerns the demand response to changed prices due to international trade. Factor content models argue for given product prices when calculating the wage effect due to increased imports. These models assume, for example, that in the absence of low-priced imports of low-tech goods consumers would buy the same amount of low-tech domestic goods despite the fact that they are overpriced. But a more likely consumer response is to buy fewer high-priced, low-tech domestic goods and to switch to, say, high-tech commodities. ${ }^{10}$ The higher this response is, the greater will factor content analysis over-estimate the positive employment effect of low skilled workers in the absence of those imports. In

\footnotetext{
${ }^{10}$ See Freeman (1995), pp. 26.
} 
principle, these effects can be taken into account by using (cross) price elasticities, but in practice these numbers are often difficult to obtain.

(iii) The increase of imports may or may not be exogenous. This argument brings into question the causality which is from trade to wages, used in many factor content models. For example, removing trade barriers in the course of several GATT rounds can, with some justification, be viewed as an exogenous import increase which establishes a clear link from trade to wages. There is every reason, however, to argue that increased imports are simply the result of an exaggerated domestic wage policy, i.e. imports are endogenous. While the resulting estimation bias for the U.S. ${ }^{11}$ may be low, if there is any at all, this may raise suspicion that it is more important for the German case due to a wage policy which aimed at increasing low wages disproportionally.

(iv) Another possible bias stems from differing production techniques between developed and emerging countries. As an extreme case, domestic sectors are non-competing rather than competing with imports employing low skilled workers because the domestic producers simply do not (or only to a small amount) produce those goods. Put differently, developing countries have become specialized producers in low-skill intensive goods. Factor content analysis understates the amount of unskilled labor in developed countries which would be needed to replace imported goods by domestic production as long as domestic labor input coefficients for skill-intensive production are used when calculating the additional domestic demand for labor. One possible way to obtain more accurate results is to measure the amount of low skilled labor in developing countries used to produce these imports. These inputs of labor must then adjusted for more skill- and capital-intensive techniques to be used in developed countries (due to the higher domestic wages). ${ }^{12}$

(v) Finally, (the mere threat of) imports may lead domestic firms to develop defensive innovations. This technical progress may even spill over to other sectors. Due to those labor saving techniques, domestic demand for unskilled labor is reduced further. While profit-maximizing firms should use labor-saving, cost-reducing technologies anyway, it may be argued that the emergence of low-wage competitors was such a drastic change in market conditions that it became a matter of survival for firms to innovate rather than the impact of internal competition itself forced them to do so.

\footnotetext{
${ }^{11}$ See Revenga (1992).
} 
The upshot of these considerations is that although factor content analysis can be a useful method to calculate the effects of trade on low skillled wages, the resulting estimates are subject to considerable imprecision. This is due to a number of corrections which in principle have to be made to usual procedures but failed to be carried out by various studies partly because of a lack of suitable data. It therefore comes as no surprise that available empirical studies arrive at different conclusions, which will be discussed below.

\subsubsection{Price Effects Analysis}

As has been mentioned at the beginning of this section, an alternative way of looking at trade effects on wages is to exploit price data. It has been argued by trade theorists that trade prices rather than trade volumes are to be considered as the central channel of transmission for analyzing impacts on labor market developments stemming from trade. As has been emphasized by Leamer (1996) the factor content of trade is jointly determined by tastes, technologies, factor supplies, and the external goods market. Hence, the factor-content approach - besides being fairly ad hoc - yields meaningful results only when comparing two equilibria where these influences are held constant.

The basic idea of the price-effects model is directly linked with the Stolper-Samuelson theorem. Increased imports from developing economies may have caused a reduction in prices of competing goods produced by domestic low skilled labor, which in turn lowers demand for low skilled workers and, consequently, reduces their wages.

The empirical application of this model to gauge effects of trade on relative wages consists of an analysis of whether import (or output) prices within and between sectors are linked to the skill mix of employment. For the predictions of the theoretical model to be correct, relative prices of low-skilled intensive goods should decline corresponding to a decline of relative wages of low-skilled workers. This framework has to be modified, however, in order to take into account the possibility of rigid factor prices, namely rigid wages. This is especially relevant when dealing with European economies as opposed to U.S. labor markets.

In order to understand the mechanism in the Heckscher-Ohlin-Samuelson (HOS) framework, two different impacts on the employment of low-skilled workers stemming from the aforementioned increase of imports from emerging countries should be

\footnotetext{
${ }^{12}$ See Wood (1995) for a more detailed description and an application to U.S. manufacturing.
} 
distinguished. First, production adjusts such that the importance of sectors which employ mainly high-skilled labor increases. In other words, a skill-upgrading between sectors takes place. Second, within sectors the fall in relative wages of low-skilled workers causes a substitution towards low-skilled workers (i.e., a movement on the firm's isoquants). ${ }^{13}$ Full employment in the HOS model requires wages to be flexible enough to balance both opposing effects.

However, there is empirical evidence that in Europe, notably in Germany, relative wages do not sufficiently respond to price and output changes. Therefore, the HOS model has to be amended. Davis (1998a, b) develops a model of trade between two countries, one of which has flexible wages, while the other imposes a binding minimum wage on unskilled labor. In his model the basic link between the minimum wage and the appearance of unemployment is that for competitive firms to pay the (high) minimum wage, this must be supported by an appropriate goods price which in turn will be attained only if the relative scarcity of the labor-intensive goods rises relative to the flexible-wage equilibrium. This will occur only if a sufficient amount of labor is unemployed. ${ }^{14}$ While the outcome of this approach is similar to the model by Krugman (1995), the approach by Davis contrasts with Krugman in that the second author treats the American flexible-wage case and the European rigid-wage case as though they were part of different global economies, whereas Davis emphasizes the links via goods trade as being crucial for understanding the stylized facts which are uncontroversal. This point will be taken up again in the next section.

In the present context, those insufficient factor price reactions to import shocks - or even adverse reactions where, as in Germany, low-wages did increase more than proportionally lead to joblessness of low-skilled workers in those sectors which use low-skilled workers intensively and whose relative product prices decline.

Without doubting the merits of these models extending the HOS theory in order to allow for rigid wages, it should be stressed that an important question remains unanswered, namely, what determines more or less rigid (relative) factor prices. These models do not provide a rigorous (dis)equilibrium framework which endogenizes wage setting.

Be that as it may, the price effects models which estimate the relationship between relative prices and wages suffer from various measurement problems due to neglected influences and/or inadequate data.

\footnotetext{
${ }^{13}$ See Lawrence and Slaughter (1993) for a discussion of these effects.

${ }^{14}$ Davis (1998a), p. 481.
} 
To begin with, all factors which influence prices and wages aside from trade have to be taken into account in a proper way. For example, the analysis should not be concerned with output prices as such, but with output prices adjusted for total factor productivity in order to correct for technical progress in the sector under consideration. These "effective prices", as they are called, are hard to estimate given measurement problems of total factor productivity. ${ }^{15}$ Measurement problems are reinforced by the observation that most of the changes in relative prices and wages took place within a sector (presumably the manufacturing sector) where very detailed data on output prices are sometimes difficult to obtain. Besides technical progress, relative price changes are subject to possible shifts in consumer preferences depending on the income elasticity of goods demand. Moreover, there are substantial difficulties in adjusting data on (trade) prices for product quality, the changes of which being likely correlated with the skill intensity of production. In addition, there may be an aggregation problem as long as final goods consist of imported and domestic inputs which differ in important dimensions. Finally, as long as unskilled labor is only a small proportion of costs (in manufactured goods to which most studies refer), it is difficult to establish a significant relationship (if it exists) between price changes and the skill mix of workers. $^{16}$

Similar problems carry over to relative wages. To some extent labor markets are segmented, both within manufacturing and between manufacturing and non-manufacturing. Hence, relative wages are influenced by sector-specific rents, union militancy and short-term disequilibria which need some time to resolve.

Like factor content models, price effects studies are associated with numerous problems which render their results questionable. Since most of the problems cannot be solved easily, if at all, it seems a feasible strategy to treat the results of both approaches as a partial evidence on how trade may affect relative wages without claiming that this represents a final verdict. This leaves us with the requirement to summarize the empirical findings with an emphasis on the situation in Germany.

\subsubsection{Empirical Findings}

Studies for the U.S. are based on factor content models as well as on price effects models and have been surveyed by Freeman (1995). Examples of factor content models include

\footnotetext{
${ }^{15}$ See Sachs and Shatz (1994).

${ }^{16}$ See Freeman (1995) pp. 28 for this point.
} 
Borjas, Freeman and Katz (1992), Revenga (1992), and Wood (1994, 1995). These models have been criticized, for example, by Leamer (1994) for reasons outlined above.

Studies which rely on price effects include Lawrence and Slaughter (1993) and Sachs and Shatz (1994). While it is difficult to give a fair assessment of all studies (including those not mentioned here), it seems safe to say that most of them, with A. Wood as probably the most notable exception, arrive at the conclusion that, although trade via competition from developing countries does affect relative wages to the disadvantage of low-skilled workers, this effect can only explain a minor component of the observed changes of the wage structure. ${ }^{17}$ The disagreement does not (so much) concern the question whether trade hurts unskilled labor in the U.S. at all, but rather the size of this effect. With respect to other countries a recent study by Dejonqueres, Machin and van Reenen (1999) for a number of OECD countries finds little support for the predictions of the basic HOS model: Even within very disaggregated non-traded sectors there are increases in skilled employment and when looking at data from developing countries it is hard to find consistent support for the trade hypothesis. These authors conclude that a combination of pervasive skill biased technical change and labor market institutions offers a more compelling alternative to the trade hypothesis.

In contrast to the existing rich literature for the U.S. economy there are only few recent studies comprising with econometric research on the effects of trade on the German labor market such as FitzRoy and Funke (1996), Haisken-DeNew and Zimmermann (1995) and Lücke (1999). ${ }^{18}$ Most of these studies find small or zero effects of trade on the prospects of the labor market for different skill groups, notably on low-skilled workers. Recent and elaborate studies have been carried out by Fitzenberger (1997, 1999a,b). The author bases his analyses on a modified Heckscher-Ohlin-Samuelson (HOS) model and distinguishes three skill types of labor (low, medium, high) rather than allowing for only manual and nonmanual workers as in other studies. Using data for 36 tradable goods industries taken from national accounts and a one percent random sample from German social security employment accounts ${ }^{19}$ and covering a period from 1970 to 1990, Fitzenberger (1997, 1999a, b) arrives at the following conclusions:

(i) Real wages were rising steadily which is consistent with price declines being comparatively larger for capital-intensive industries. This results in overall capital

\footnotetext{
${ }^{17}$ Wood (1994) argues that trade effects are responsible for most of the trends in recent U.S. labor market trends.

${ }^{18}$ See also Hesse (1996) and Paqué (1998).
} 
intensity to increase over time. The estimates use the trend of the deflator of aggregate value added as a proxy for the trend of user costs of capital. Lower relative user costs of capital (as observed in some time periods) may induce a higher capital intensity of production, i.e. a substitution away from low-skilled labor. To the extent that capital and high-skilled labor are complementary employment and/or wages of the latter increase (depending on the supply of high-skilled labor, see below).

(ii) The relative wages of both low-skilled and high-skilled workers have been increasing relative to medium-skilled workers. ${ }^{20}$ While these changes are small as compared with the U.S. experience they are, at first glance, inconsistent with the Stolper-Samuelson theorem because the empirical evidence on product prices shows that relative price declines were stronger for those industries with high intensities of low-skilled and highskilled labor. The Stolper-Samuelson implications of these price changes would be (notably in equilibrium) that wages for low-skilled and high-skilled workers should have declined relative to medium-skilled workers. However, in light of a modified HOS model by allowing for wage floors which prevent relative wages of low-skilled workers from falling, employment trends for low-skilled workers are consistent with trade effects predicted by such a model. In these industries which use low-skilled labor intensively and which experience disproportionate price declines, relative wages of low-skilled workers were increasing rather than falling. Hence, the respective employment share of these industries as well as the employment of low-skilled workers within these industries decreased. While this holds for low-skilled labor, it is inconsistent for high-skilled workers. For this group, other factors must be at work, namely technological progress which will be discussed in the next section. As a preview, however, Fitzenberger's conclusion is that the evidence is consistent with trade hurting low-skilled workers whereas technical progress positively affects high-skilled labor.

More specifically, in a more structural estimation approach Fitzenberger (1999a) estimates "mandated" factor price changes resulting from trade and from technical progress using an approach suggested by Leamer (1996). Leamer's analysis is based on a long-run HOS model where the relationship between (a vector $p^{g}$ of) output prices and (a vector $w$ ) factor remuneration rates is described by a set of zero profit conditions, $p^{g}=A^{\prime} w$, with $A$ being a matrix of factor input intensities. The equation to be estimated regresses output price

${ }^{19}$ The so-called "IAB-Beschäftigtenstichprobe". 
changes $\Delta \ln p^{g}$ across industries $i$ on factor shares $\theta$ for capital and $j=3$ types of labor (low/medium/high-skilled $(U, M, H))$ :

$$
\Delta \ln p_{i}^{g}=\theta_{K, i} \cdot \hat{\alpha}_{K}+\sum_{j=1}^{3} \theta_{j, i} \cdot \hat{\alpha}_{j} \quad j=U, M, H
$$

The estimated coefficients $\hat{\alpha}$ on each factor share represent the estimated change of the factor remuneration rate resulting from a change in output prices which are required for long-run zero profit conditions to be satisfied (Stolper-Samuelson channel).

To restate, $\Delta \ln p^{g}$ in equation (1) is the element of price change which results solely from trade effects, but $\Delta \ln p^{g}$ is not observed. As a second determinant Leamer (1996) recognizes technical progress which is measured by total factor productivity $(T F P)$ growth. This variable, in turn, is obtained as the Solow-residual from the following regression

$$
\Delta \ln y_{i}=\theta_{K, i} \cdot \hat{\beta}_{K}+\sum_{j=1}^{3} \theta_{j, i} \cdot \hat{\beta}_{j}+\text { Residual, } \quad j=U, M, H
$$

where $y$ denotes output, $\hat{\beta}$ are the estimated regression coefficients, and all other variables retain their prior meaning. To disentangle the effects of technological change from the effects of globalization (and other sources of product price variability) requires knowledge of the price changes induced by TFP growth. Leamer (1996) assumes all sectors to exhibit the same "rate of technological pass-through" to product prices, namely

$$
\Delta \ln p_{i}^{t}=-\lambda \cdot \Delta \ln T F P_{i}
$$

where $\lambda$ is the pass-through rate common across all sectors and $\Delta \ln p^{t}$ denotes the inflation rate induced by technical progress. Observed price changes $\Delta \ln p_{i}$ are then the sum of globalization and technology induced price changes weighted by a constant passthrough rate: ${ }^{21}$

$$
\Delta \ln p_{i}=\Delta \ln p_{i}^{g}-\lambda \cdot \Delta \ln T F P_{i}
$$

While equation (3) describes output price changes due to TFP growth ("complete passthrough"), TFP growth, on the other hand, could increase factor remuneration rates without changing output prices ("no pass-through"). With a constant "pass-through rate" across

\footnotetext{
${ }^{20}$ Skill-groups are defined as in section 2.1 .

${ }^{21}$ Without the assumption of a constant pass-through rate common across sectors globalization and technology effects cannot be identified.
} 
industries, the sign of changes to remuneration rates can be estimated by regressing $T F P$ growth across industries $i$ on the respective factor shares:

$$
\Delta \ln T F P_{i}=\theta_{K, i} \cdot \hat{\gamma}_{K}+\sum_{j=1}^{3} \theta_{j, i} \cdot \hat{\gamma}_{j} \quad j=U, M, H
$$

The estimated regression coefficients $\hat{\gamma}$ on each factor share $\theta$ now represent the estimated change in the factor remuneration resulting from technological progress under the "no passthrough" assumption.

Taken together, equipped with this methodology, the differential qualitative impacts of technology and trade can, to some extent, be evaluated by regressing price changes and TFP changes on the respective factor shares. This is the approach used in Fitzenberger (1997, 1999a, b) enriched by the introduction of wage floors in order to cope with downward inflexible nominal wages in Germany.

Table 2 displays his results for export prices, import prices, and output prices because each of these price indices within one sector is subject to one or the other measurement problem: goods produced within one sector are not homogenous, producers may discriminate between domestic and foreign customers, output prices are based on value added whereas export and import prices include total value of production, and so on. Therefore, using three different prices is a test of the robustness of the estimates. Nevertheless, as is carefully noted by Fitzenberger, the emphasis should be on the qualitative impact rather than on the numerical value of the coefficients. ${ }^{22}$

As can be seen from table 2, price changes are only favorable to relative real wages of medium-skilled workers but adversely affect relative real wages of low-skilled and highskilled workers. Put differently, the impact of observed price changes on relative real wage changes across skill groups follows an inverted $U$. These results are robust with respect to the type of price change under consideration. On the other hand, there are marked differences with respect to orders of magnitude between import and output prices, although the aforementioned caveats should be kept in mind.

In order to distinguish between trade and technology effects, inspection of the last column in table 2 reveals that TFP growth is favorable both to low-skilled and high-skilled labor relative to medium-skilled labor.In other words, TFP growth's impact on relative real wages

\footnotetext{
${ }^{22}$ As also noted by Fitzenberger, some of the coefficients exhibit implausible orders of magnitude.
} 
Table 2: Trade Effects on Wages ${ }^{\text {a) }}$

\begin{tabular}{|c|c|c|c|c|}
\hline \multirow{2}{*}{$\begin{array}{c}\text { Explanatory } \\
\text { Variables }\end{array}$} & \multicolumn{4}{|c|}{ Dependent Variables $^{\text {b) }}$} \\
\hline & $\begin{array}{c}\text { Export Price } \\
\text { Changes }\end{array}$ & $\begin{array}{c}\text { Import Price } \\
\text { Changes }\end{array}$ & $\begin{array}{c}\text { Output Price } \\
\text { Changes }\end{array}$ & $\begin{array}{c}\text { TFP } \\
\text { Growth }\end{array}$ \\
\hline$\theta_{K}$ & $-0.742(4.2)$ & $-0.291(2.4)$ & $-0.613(3.0)$ & $0.489(4.1)$ \\
\hline$\theta_{U}$ & $-1.287(2.2)$ & $-1.417(3.4)$ & $-0.725(1.1)$ & $1.171(2.9)$ \\
\hline$\theta_{M}$ & $0.734(3.3)$ & $0.481(3.1)$ & $0.894(3.5)$ & $-0.520(3.5)$ \\
\hline$\theta_{H}$ & $-2.238(2.9)$ & $-1.895(3.5)$ & $-3.692(4.1)$ & $2.525(4.9)$ \\
\hline
\end{tabular}

Notes: a) See text for explanations.

b) Relative changes compared with 1975 . Output price changes are relative to deflator of aggregate value added. t-values are in brackets.

Source: Fitzenberger (1997), table 3.

across skill-groups follows a $U$-pattern. While this result is intuitively plausible for highskilled workers, it comes as a surprise for the case of low-skilled workers, to say the least, and deserves further analysis.

Taken at face value, however, and combining the inverse $U$-pattern of total price effects and the $U$-pattern of technological progress, yields the conclusion that negative price effects, stemming from globalization, are estimated for low-skilled workers. Since their wages have not only been inflexible downwards but increased improportionally, the aforementioned conclusion suggests that international competition is likely to be responsible for the negative trend in the demand for unskilled labor resulting in higher unemployment of this group.

\subsubsection{Conclusion}

In summing up, what can be learnt about the impact of increased free trade on the relative position of low-skilled workers from these studies for Germany? By and large, the overall impression is not so much distinct from the U.S. experience. There is empirical evidence that supports the view that international trade had an impact, although perhaps small and not always statistically significant, on the structure of wages and employment to the disadvantage of low-skilled workers. From the viewpoint of the beginnings of the 1990's, 
when the sample period of most studies under review ended, the threat of globalization should not be exaggerated. To some extent this result is disappointing, if not puzzling, since it is at odds with purely anecdotal evidence. Given the progress of various GATT negotiations such as the Tokyo and Uruguay Rounds and the regional free trade areas in Europe and North America, it is astonishing that this does not show up more in product prices. Either the advanced economies on balance have not in fact become much more open to trade, or firms in developed countries have upgraded their product mix in the face of foreign competition. ${ }^{23} \mathrm{Be}$ that as it may, however, trade pressures on wages and employment may persist and may become even stronger as China, India, and some African economies become integrated into the world economy. ${ }^{24}$ While policy implications are relegated to the final section it suffices to say that protection definitely does not constitute an appropriate policy response. Efforts for an upgrading of the qualifications of low-skilled workers and a wage structure flexible enough to meet the challenges from trade, as well as efficient measures to circumvent the working-poor phenomenon, are suitable, albeit imperfect, policy responses to cope with challenges stemming from international competition.

\subsection{Skill-Biased Technical Progress}

As has been outlined in section 2.1, by any measure, simple or complex, employees in Germany have, on average, become more skilled during the past decades. From this, a standard textbook application of a given downward-sloping demand for labor function for workers of a particular skill level and a shift towards a larger supply of skilled workers would have predicted that the wages of high-skilled in relation to low-skilled workers should have been declining during that time period. However, this is not what we observed. Wage growth for high-skilled full-time male workers, as depicted in figure 1, was higher compared to that of medium-skilled workers. An obvious explanation suggests that the rise of the supply of high-skilled workers has been outpaced by shifts in the demand for skilled workers so that the high-skilled wage premium has increased. ${ }^{25}$

The required changes in the demand for high-skilled labor may be driven by two forces, namely an increase in the relative output of the sector that uses high-skilled workers

\footnotetext{
${ }^{23}$ See Slaughter and Swagel (1997).

${ }^{24}$ This depends, of course, on the extent of which the products of these countries are still produced in Germany and/or whether these countries compete with other (developing) countries.

${ }^{25}$ See Johnson (1997) and Topel (1997).
} 
intensively (sector biased technological change) and skill-biased (or low-skilled labor saving) technological change.

The other side of the same coin is that these sources may be blamed for labor market problems of low-skilled workers. They either experience a decline in their relative wage or in the absence of wages flexible enough to square with these developments, their employment opportunities are severely damaged. This is the case in Germany, where lowskilled labor bears the major - yet not the entire - burden of unemployment.

While this view arguably gives a clear explanation of what happened, it is not without its problems. At least it has to be modified and extended with regard to several aspects.

For verification of this view it is not sufficient to show that technological change is the driving force behind the rising demand for high-skilled workers. In addition, it has to be shown why or what type of technological progress accelerated after the beginnings of the 1970 's. Which factors, viewed as important of the previous two decades, were absent before the beginning of the 1970's when there was virtually no unemployment - skilled or lowskilled - in Germany? Presumably most new technologies are supposed to have an adverse impact on the demand for low-skilled workers. History provides a huge body of examples that industrialization is synonymous with (low-skilled) labor saving technical progress. Obvious examples are the diffusion of computers and related technologies and changes in the organization of work associated with effectively utilizing these technologies. ${ }^{26}$ But the discussion concerning the extent to which computers (or pencils, too) have changed the wage structure (in the U.S.) has not led to an unanimous answer, let alone uncontroversal evidence that the impact of these forces accelerated in the past decade. ${ }^{27}$

A second point concerns the role of demand factors in comparison with supply-side determinants. In the light of flexible wages in the U.S. and rigid wages in Europe, the unemployment across skill groups should be more widespread in the U.S. as compared with Europe. But the correlation between changes in inequality and changes in the ratio of the unemployment rate of the unskilled to skilled across major OECD countries is anything but significant. Indeed, as has been pointed out by Nickell and Bell (1996), while real wages of bottom-decile Germans are twice those of bottom-decile Americans on a purchasing-power-

${ }^{26}$ See Autor et al. (1998) and Lindbeck and Snower (1996) for each of these aspects.

${ }^{27}$ See the discussion between Krueger (1993) and DiNardo and Pischke (1997). For the U.K. Haskel (1999) finds for the time period over 1980 to 1989 that in the manufacturing sector the average skill premium rose by around 13 percentage points, the half of this increase being explained by computer introduction. Entorf et al. (1999) show in an empirical study for France that computer users are better paid than nonusers (15 to 20 per 
parity, unemployment rates of low-skilled workers in West Germany have been similar to those in the United States and even lower than those in Britain (in both countries relative wages of the unskilled have fallen). ${ }^{28}$ As is emphasized by these authors and also shown by Freeman and Schettkat (1999), using the International Adult Literacy Survey among other data sets, the German workforce is more skilled than the U.S. workforce especially at the lower skill levels. Hence, Freeman and Schettkat (1999) conclude that the differing dispersion of wages is not a major contributor to differences in employment rates between Germany and the U.S.. Moreover, U.S. unemployment rates of low-skilled workers may even exceed those in West Germany, if one takes account of the high percentage of lowskilled American men who are in prison or jail: according to Freeman (1998) the percentage of males relative to male employed who were incarcerated (prison, jail) or under supervision (incarcerated, probated, paroled) in the U.S. in 1995 amounted to 2 and 7 percent, respectively. Tentative guess estimates of these numbers for West Germany are considerably lower. Both aspects taken together, the suspicion may be raised that U.S. lowskilled unemployment rates have been even higher than in West Germany despite the higher inequality especially at the bottom of the wage structure in the U.S.. While these observations do not imply that a more flexible wage structure fails to be a promising tool for creating additional jobs, the broad-brush description "Europe Jobless, America Penniless" (Paul Krugman) seems to overemphasize the point. Put differently, it does not suffice to look at demand shifts due to technical progress in order to explain observed trends. Supply factors as well as labor market institutions should be part of an appropriate appraisal. ${ }^{29}$

Even if these two caveats - acceleration and supply-side factors - are put aside, two other aspects have to be considered carefully in order to better gauge causality links and empirical evidence. The first is the aforementioned distinction between sector-biased and skill-biased technical progress, the second concerns the endogeneity of technical progress.

The impact of technical progress on relative wages depends on whether the technical progress favors a certain factor of production (factor-biased technical progress) or occurs in certain sectors (sector-biased technical progress), whether technical progress is pervasive

cent more) but that these workers were already better compensated before the introduction of new technologies.

28 As has been pointed out by Burda (1998) the link between skill-biased technical change and relative unemployment rates may become blurred, however, if labor supply reacts on wage changes and/or demand is influenced by labor demand.

${ }^{29}$ For example, Gregg and Manning (1997) stress the importance of government involvement in education and Mortenson and Pissarides (1999) the role of the unemployment compensation and dismissal regulations. See Topel (1997) for a summary of supply-side determinants of wage inequality. See Manacorda and Petrongolo (1999) for an analysis of skill mismatch and unemployment in OECD countries. 
(occurring more or less simultaneously in all sectors) or is isolated (occurring only in one sector) and whether technical progress is worldwide or country-specific. In the present context factor-biased technical progress means skill-biased technical progress which rises the employment of skilled workers relative to unskilled workers at given relative wages.

The distinction between isolated versus pervasive technical progress and skilled-biased versus sector-biased technical progress is important for an assessment on whether a certain sector where technological change occurs is critical or whether a certain group is affected. Three important cases can be distinguished [Haskel and Slaughter (1998)]:

(i) Assume exogenous product prices and an isolated technical progress. While in a onesector, two-factor, two-country economy it is obviously the skill-bias of technical change that matters, this result is reversed in a two-sector open economy where the sector bias of an isolated technological change matters in determining relative prices and not the skill-bias. ${ }^{30}$ The intuition behind this is that technological progress in one sector increases its profitability (at given product prices and initial factor prices) which leads to an expansion of production in this sector and, consequently, to demand increases for the factor employed relatively intensively in that sector. Consequently, relative wages will adjust (given fixed labor supply) until the profit opportunities are arbitraged away.

(ii) Now assume a pervasive technical progress but otherwise assume the same model. Will sector-biased technical progress rather than skill-biased technical progress still drive relative-wage changes? This is a key question because, as will be shown below, empirical evidence suggests that technical change has been pervasive. However, the answer is ambiguous. Additional information about several bias parameters is required. For example, as long as more extensive skill-upgrading in a sector is associated with greater cost reductions in that sector, then it is likely that wage changes are directed by the sector bias of pervasive skill-biased technical progress. ${ }^{31}$

(iii) Finally, assume endogenous product prices in a two-sector open economy where both countries share identical production technologies so that an innovation in one country becomes a worldwide innovation that affects world supply and thus product prices. As

\footnotetext{
${ }^{30}$ For a formal proof see Haskel and Slaughter (1998) on which the following explanations draw. As has been pointed out by Leamer (1996) this may be only a first-order result, however. Moreover, as has been pointed out by M. Lücke in Siebert (1999), the considerations by Haskel and Slaughter can be traced back to the work by Jones (1965) who formulates a more general equilibrium approach with the Haskel-Slaughter model as one special case.
} 
is shown by Haskel and Slaughter (1998) while the total effect of isolated, as well as pervasive technical progress on relative wages is ambiguous in all cases, in many cases the sector bias of technical change is still the key determinant of relative-wage changes, for example if factor substitutability in production is sufficiently small or if a non-tradable sector exists which can, to some extent, absorb workers released by technology.

The upshot of this discussion is twofold. First, most of the literature has focussed on an isolated technical change in a model with fixed product prices. In this case it is clear that changes in relative wages are driven by the sector-bias of technological change. Second, relaxing one or both of those assumptions and allowing for pervasive technical progress and/or endogenous product prices renders the effect of technical progress on relative-wages ambiguous.

How important are these distinctions in empirical work? First, some studies identify technology trends by total factor productivity growth based on a log-linear specification of the production technology such as Cobb-Douglas. ${ }^{32}$ In this case sector-bias and skill-bias are observationally equivalent, however. Second, according to Krugman (1995) the closedeconomy properties of a skill-biased technical progress affecting the wage structure carry over to a pervasive skill-biased technical progress in an integrated world economy consisting of many small open economies each experiencing such a technical change. As has been shown by Berman, Bound, and Machin (1998) there is sufficient evidence for a skill-biased technical progress to be pervasive. ${ }^{33}$ Moreover, it is intuitively hard to argue that technological changes such as the use of personal computers and microprocessors are not widely adopted in, say, major OECD countries. ${ }^{34}$

It goes without saying that, in order to be applicable for Europe, the assumption of flexible wages and prices has to be modified. As has been shown, however, by Landmann and Pflüger (1996) the aforementioned results for a pervasive skill-biased technical change can be transferred to economies with rigid wages, with the important exception, of course, that the lack of wage flexibility results in higher unemployment. The authors stress, however,

\footnotetext{
${ }^{31}$ A pervasive skill-biased technical progress is sector-biased towards sector 1 when this sector experiences a larger increase in the employment of skilled workers relative to unskilled labor than does the other sector.

${ }^{32}$ See the survey of the micro-econometric evidence by Chennells and van Reenen (1999).

33 These authors conclude that also developing countries experience a skill-biased technical progress and an increase of relative wages of skilled workers.

${ }^{34}$ In an open-economy product-cycle model Butler and Dueker (1999) estimate for several major OECD countries that a 10 percent increase in the domestic (foreign) innovation rate leads to a 3 percent increase (decrease) in the high-tech wage rate, relative to the low-tech wage rate.
} 
the importance of wage flexibility for international trade by showing that the same skillbiased technical progress which reduces North-South-trade (due to the increase in the importance of the low-tech sector relative to the high-tech sector) in a world of flexible wages, will just work the other way around if wages are rigid.

As has been mentioned, a second aspect is concerned with the endogeneity of technical progress. Endogeneity can be analyzed from two different, albeit not mutually exclusive, viewpoints. First, why do new technologies complement skills rather than to save on skilled labor (as many examples from the past suggest, such as the spinning jenny weaving machines, printing cylinders, or the assembly line). One answer, given by Acemoglu (1998), starts from the premise that new technologies are not complementary to skills by nature, but by design. The author shows in a model with endogenous technical progress that the direction of technical progress is determined by the size of the market for different inventions, i.e., the higher the number of skilled workers, the larger the market for technologies that complement skills and, hence, the more new technologies will be invented. Second, absorptive capacities may play a role. Caselli (1999) emphasizes the importance of cognitive ability and costs of learning (including credit constraints). Moreover, as is shown by Lloyd-Ellis (1999), also in a model with endogenous technical change, wage inequality rises when the rate at which new technologies are introduced exceeds the rate at which they are absorbed because of increasingly fierce competition for the scare, technologically mobile workforce.

Focussing on skill-biased technical change, its impact on employment proportions of skilled and unskilled labor and on relative wages also depends on who becomes more productive in which sort of jobs. ${ }^{35}$ First, changes in the relative demand for skilled workers are primarily caused by an extensive skill-biased technical progress which makes skilled workers become more efficient in jobs that were formerly done by unskilled workers. For example, the use of robotic techniques in manufacturing leads to a higher demand for engineers. Other things equal this drives up the skilled wage rate, while the wage of the displaced unskilled workers falls so that the net effect on the average wage in the economy is ambiguous. But the impact of technical change may, of course, also go the other way around in the sense that it is skilled-labor saving rather than unskilled-labor saving. An example frequently referred to in the literature is the introduction of assembly lines which may favor low-skilled labor due to its mainly simple routines. Second, intensive skill-biased technical progress means that skilled workers become more productive in tasks they already perform. For instance, the 
introduction of personal computers including more advanced software packages raises the productivity of an architect designing a new building. ${ }^{36}$ This type of technical change will only increase the relative demand for skilled workers to the extent that the elasticity of substitution between the two types of labor $(\sigma)$ exceeds unity because otherwise, if $\sigma=1$, the rise of the wage rate of skilled labor leads employers to fully substitute unskilled for the higher-wage skilled labor. Thirdly, skill-neutral technical change increases the efficiency of all types of labor proportionally leaving the relative employment share and the wage structure unaffected.

This leaves us with the question as to econometric estimates of substitution elasticities between low-skilled, medium-skilled, and high-skilled workers. For the U.S., Bound and Johnson (1992) and Katz and Murphy (1992) derive substitution elasticities between skilled (college) and low-skilled (high school) labor of about 1.7 and 1.4, respectively. Estimated substitution elasticities for West Germany vary a great deal between different studies, depending on which industry is under consideration, the time period, the measurement of skills, and the production technology assumed. In order to give an impression of the range of estimates, the results from some studies are reported. By and large, they all base their estimate on a translog cost system, use individual earnings data from social security accounts data ("IAB-Beschäftigtenstichprobe") for wages (and employees) and other sources for employees such as disaggregated national accounts or an establishment panel survey. Hence, these studies are to some extent comparable although differences in their methodology still remain. Steiner and Mohr (1998) find that the substitution elasticity between unskilled and skilled is rather low for all industries, namely $0.13(0.09)$ and 0.08 (0.9) for males and females, respectively (standard errors in brackets), lacking convincing significance. For some sectors, however, quite large and statistically significant substitution elasticities are estimated such as $1.37(0.4)$ for male workers in the construction and transportation sector and $0.84(0.2)$ for females employed in the service sector such as health care, cleaning (in constrast to the business sector). For male employees working in the manufacturing sector these authors obtain an estimate of 0.33 (017) which is roughly consistent with Falk and Koebel (1999) for medium and unskilled labor. The latter authors estimated an insignificant substitution elasticity between unskilled and high-skilled workers. Fitzenberger and Franz (1998) obtain substitution elasticities between unskilled and skilled male employees which vary between 0.4 in mechanical engineering and about 2.5 in trade.

\footnotetext{
${ }^{35}$ See Johnson (1997) for the following.
} 
In contrast to these estimates, Bellmann et al. (1999) claim substantial substitution elasticities such as $3.06(0.4)$ between unskilled and medium-skilled blue collar workers and $1.10(0.4)$ between unskilled and high-skilled blue collar workers.

Equipped with these numbers, it comes as no surprise that studies (for West Germany) differ in their assessment on the likely impact of skill-biased technical progress on the structure of employment and wages, although there is hardly any disagreement that such an influence does exist. Steiner and Mohr (1998) as well as Steiner and Wagner (1998) conclude that the rather uniform decline of the skills ratio across all sectors of the West German economy and the much stronger trend decline in manufacturing industries characterized by a relatively high total productivity growth seems compatible with the hypothesis of unskilled laborsaving technological change, although the much faster decline of the skills ratio for women compared with men remains unexplained. They emphasize that supply-side factors, in particular the general upgrading of the level of educational and vocational qualifications, has also played an important role. Fitzenberger and Franz (1998) reach similar conclusions. Focusing on the business-related services sector in West Germany, Kaiser (1999) analyzes the impact of investments in new technologies (as a proxy for technical progress) on the demand for heterogenous labor on the basis of the Mannheim Innovation Panel in the Service Sector (MIP-S). He identifies skill-biased technical progress as an explanation for the decline in relative demand for low-skilled labor. Falk and Seim (1999) use the same data and explore the link between information technology and workers' skill levels for the German service sector. Their results exhibit a small but significant impact from information technology on the employment share of university graduates while this effect is reversed for unskilled labor.

As has been outlined before, wage bargaining is not exogenous but should be integrated in these models. Klotz et al. (1999) as well as Fitzenberger (1999a,b) are two studies which focus on the importance of wage policy. The former authors analyze the impact of technical progress on the skill structure of employment and wages by means of an insider-outsidervariant of a right-to-manage model. Indirect effects of technical progress on employment resulting from the wage bargaining process prove to be quantitatively important: in different industries job losses due to technical progress for the low-skilled relative to the high-skilled are either generated or compensated through wage policies. Fitzenberger (1999a,b) finds a skill bias in labor demand - mainly the result of technical progress, although the evidence is

\footnotetext{
${ }^{36}$ Clearly, the adoption of personal computers also led to additional jobs for skilled workers besides increasing their productivity in their initial workplaces, see Johnson (1997), p. 51.
} 
also consistent with international trade causing a deterioration in the labor market position of low-skilled workers - and that, at the same time, higher wage flexibility (both between and within skill groups) could have alleviated the dispersion in unemployment rates across skill groups. With regard to wage bargaining, he finds some evidence for a moderation of wage demands for a particular skill group in the short run when unemployment increases but little evidence for a long-run reaction when unemployment has become persistent.

How do these results relate to more recent international evidence? Lücke (1999) investigates the impact of changes in sectoral value-added prices and total factor productivity on the equilibrium relative wage of low-skilled workers in eleven high-income OECD countries during the period 1970 to 1992 . His econometric model uses the sum of product price changes and total factor productivity growth as left hand side variables and base-period factor income shares as the right hand side variables (similar to the procedure outlined in some detail in the previous section). The author finds that the sector bias of total factor productivity growth shifted from benefitting unskilled-labor-intensive industries during the 1970 's to benefitting human-capital-intensive industries during the 1980's. More specifically, it is not technological change as such, but rather the shift in the sector bias of total factor productivity growth that is (partly) responsible for the observed trend reversal in earnings inequality around 1980, as mentioned before.

\subsection{Summary and Implications}

The sequence of the aspects on which the literature agrees or disagrees comes as a surprise. There is now a fairly broad consensus on the basic facts about the development of wages and employment across skill groups, despite unresolved methodological differences. How to explain these trends is subject to considerable disagreement, in particular to what extent trade liberalization and skill-biased technical change share a major responsibility. Remarkably, however, the consensus is again on policy implications. Virtually no study favors protection against imports from developing countries, or against a skill-biased technical progress (taxes on computers?), but most agreee on sufficient wage flexibility, better education and training, and some type of income redistribution.

More specifically, by any measure, sophisticated or simple, the German work force has become more skilled in the past few decades. While the wage structure across skill groups does not display such a rigid and highly compressed structure as is frequently alleged, there is empirical evidence that the existing flexibility was at least insufficient to meet several 
challenges, if not that wage policy aiming at more equality has worsened the employment prospects of low-skilled labor. It goes without saying that wage moderation and a more flexible wage structure are not the only measures, and they cannot be the only measures against unemployment. But they have to contribute.

The causes of the observed trends in wages and employment across skill-groups are under dispute. However, a tentative consensus seems to emerge (at least for Germany) that trade and technical change are neither the sole explanations, nor are they mutually exclusive. Most studies agree that in addition to these forces which drive the demand for labor, supplyside factors play an important role such as the upgrading of skills by the work force, higher female labor force participation rates, and (perhaps) immigration. Moreover, almost no study clearly and convincingly rejects trade or technical change as one of the possible explanatory influences. As a promising preliminary strategy, it may not be inappropriate to claim that both forces are at work - which is what intuition, anecdotical evidence, and the (intelligent) lay-man would suggest - and, perhaps more risky, to put them on a more or less equal footing.

The dispute over the extent that international competition and/or skill-biased technological change are the driving forces, at least for wage policy, but also for other policy measures, should not overlook that there is virtually no escape from both developments and that this is certainly true for export-oriented Germany (more devoted to international trade compared to, say, the U.S.). Protection against imports from developing countries is, of course, possible (in the short run) and in the public arena there may be a (political) backlash against globalization. But the costs of such protection would outweigh its benefits on a grand scale. ${ }^{37}$ Therefore, other sorts of policies which provide a less expensive solution to the undisputable economic and social problems of low-skilled workers should be applied. The same holds, by and large, for the impact of skill-biased technical change. Again, to stem the tide is completely hopeless as history tells us. In addition, policy options are limited, especially if the short run is concerned. On the other hand, a more flexible wage policy can mitigate some of the adverse effects in the short-run. The problem is that the social consequences of both, trade and technical change, are concentrated mainly among the lowskilled, low-wage earning members of the society. Hence, a wage structure more flexible downwards may be, to some extent, a suitable tool to create jobs especially in the service sector. But in order to avoid the unwarranted phenomenon of the "working poor" such a

\footnotetext{
${ }^{37}$ Such a protection will be impossible when trade with Central and East European economies in an enlarged European Union is concerned.
} 
wage policy must be accompanied by adequate (financial) support of these workers. Clearly, this is more easily written than achieved in an efficient manner, i.e., to provide sufficiently strong incentives for working and (further) vocational training, while providing financial help at the same time. Some adverse side effects of these measures, hopefully minor, seem to be inevitable, but could be viewed as a (temporary) tax to compensate loosers, through no fault of their own, of international competition and skill-biased technical progress. The same holds for financing better education and vocational training as the most promising policies to be implemented. While improving the skills by an efficient educational and vocational training system falls to a considerable extent, albeit not completely, in the realm of public policy, there is reason to argue that, at least in Germany, the efficiency of these policies can be improved. These aspects are, however, beyond the scope of this paper. 
wage policy must be accompanied by adequate (financial) support of these workers. Clearly, this is more easily written than achieved in an efficient manner, i.e., to provide sufficiently strong incentives for working and (further) vocational training, while providing financial help at the same time. Some adverse side effects of these measures, hopefully minor, seem to be inevitable, but could be viewed as a (temporary) tax to compensate loosers, through no fault of their own, of international competition and skill-biased technical progress. The same holds for financing better education and vocational training as the most promising policies to be implemented. While improving the skills by an efficient educational and vocational training system falls to a considerable extent, albeit not completely, in the realm of public policy, there is reason to argue that, at least in Germany, the efficiency of these policies can be improved. These aspects are, however, beyond the scope of this paper.

\section{Labor Market Effects of EMU}

European Monetary Union (EMU) obviously provides several links to the aspects analyzed in the previous sections. There is the fear or the hope (as you like it) that competition will become stronger due to reduced transaction costs and a higher price transparency resulting from a single currency. Moreover, new challenges for wage policy are claimed to have arisen due to the loss of nominal exchange rates as possible shock absorbers. As Horst Siebert (1998) puts it: "A monetary union assigns increased importance to the labor costs in the individual countries during an adjustment process after a disturbance" (p. 7). If so, this is to what extent? This is the basic question which this section addresses to.

The pivot of all possible changes is, of course, the removal of flexible nominal exchange rates and the introduction of a common monetary policy within EMU. At first glance this may have quite a few effects on labor market issues such as

- a greater transparency of all prices and wages and, as a consequence, more competition within EMU, enforced by the reduction of transaction costs through the use of a single currency,

- the loss of nominal exchange rate adjustments as a balancing tool in case of diverging economic developments between EMU-member countries,

- the protection against an appreciation of the national currency that is not justified by "real" factors but by speculative capital movements which caused job losses nevertheless, 
- a monetary policy which definitely aims at price level stability and, hence, disciplines wage policy, thus favoring more employment.

While this section mainly focuses on wage policy as a possible substitute for nominal exchange rate adjustments, a few comments on two of these arguments suffice.

The reduction in transaction costs and/or the higher price transparency are likely to cause an increase in intra-EMU-trade, but these effects should not be exaggerated. In fact, they are expected to be rather small. In the past few years, the bilateral nominal exchange rates between members of the European Monetary System (EMS) have been, with few exceptions, fairly stable. Therefore, costs of hedging have not been very high, and their decline will not have a major impact. Moreover, transaction costs for consumers, e.g. tourists, have fallen due to the extended use of credit cards. ${ }^{38}$ Finally, it will never be found out how many foreign goods were not purchased by consumers (and firms), simply because they were unable or unwilling to convert foreign prices into prices expressed in their own currency; now however they will consume because all prices are expressed in EURO. Similar arguments hold for wage transparency within EMU. To avoid possible misunderstandings, this is not to deny any effects of reduced transaction costs and increased transparency of wages and prices, but to deemphasize claims for great importance. ${ }^{39}$

Secondly, while the European Central Bank (ECB) can be certainly expected to carry out a stability-oriented monetary policy, the Deutsche Bundesbank has also pursued such a policy mostly successfully. The view that monetary policy of the ECB will discipline wage policy usually more than former European central banks did, may be correct for some countries, however not so much for Germany. In other words, while other countries may have been tempted to move on the Phillips curve in order to stimulate employment by an excessive monetary policy, the Deutsche Bundesbank clearly was not tempted, regardless of the prospects of such a cure. Therefore the claim "Do not get seduced by the fallacy of the short-run Phillips curve" (Siebert (1998), p. 12) is surely correct, but does not give a new insight for wage policy in Germany. Related dangers are to be sought in other areas.

This leaves us with the important problem of the extent to which wage policy has to serve as a substitute for nominal exchange rate adjustments in the case of divergent economic

\footnotetext{
${ }^{38}$ Newspapers used to display charts showing how much a person has to sacrifice from an initial amount of money in each bureau de change when travelling through all pre-EMU-member states. Clearly, only a fraction of the initial amount of money is left at the end - but how many people undertake such an activity?

${ }^{39}$ Burda (1999) even suspects that EMU will lead to an "inwardization" of European markets with the implication that monopolistic power in price setting increases. As a consequence this will increase incentives not to adjust prices.
} 
developments between EMU-member countries. It may be useful to analyze this aspect by dealing with the following questions in turn:

(i) Are there any other mechanisms readily available which may serve as a substitute for nominal exchange rate adjustments?

(ii) To what extent have nominal exchange rates of the Deutsche Mark vis-à-vis other preEMU-countries been used as an adjustment mechanism in the past few years?

(iii) What type of "diverging economic developments" can, in principle, be equilibrated by nominal exchange rate adjustments?

(iv) What are the perspectives from this for wage policy in Germany?

To begin with substitution mechanisms for nominal exchange rate adjustments, there are four possible options: labor mobility, capital mobility, relative price changes, and financial transfers between EMU-member countries. While all three substitutes may be able to perform the task, in theory, in reality they are unsufficient or unwarranted.

Basically, regional shocks affecting the labor market could be offset by an increased mobility of workers. Workers from a particular region that is struck by a negative supply shock resulting in unemployment could migrate to regions that are not affected. It is assumed that thus a balancing (between the regions) achieved by an adjustment of nominal exchange rates or other adjustment mechanisms, which are yet to be discussed, would be no longer necessary.

A critical evaluation of this adjustment mobility can depart from two basic questions, namely on the one hand whether the required mobility of labor is present in the EU, and on the other hand, whether it is at all desirable.

Most empirical studies show that labor mobility within EU member states is low for example in comparison to that of the US and thus not sufficient to serve as a shock absorber to the extent envisaged. ${ }^{40}$ Decressin and Fatás (1995) and Eichengreen (1990) show that for example regionally confined shocks and regional unemployment are offset far quicker by interregional migration in the US than in the EU member states examined by them. The basic causes for this low labor mobility are above all language barriers, the differences in the efficiency of housing markets, institutional barriers for example in the area of social security systems or the acknowledgement of vocational degrees and diplomas as well as general preferences for settling down in one region, as it can also be observed in Germany.

\footnotetext{
${ }^{40}$ See Gros and Hefeker (1999).
} 
On the other hand, a high regional mobility is not necessarily to be assessed in positive terms. There remains the question whether it is desirable that entire districts degenerate to (industrial) waste lands and the cultural diversity of EMU potentially becomes somewhat leveled.

Despite a possible slightly lower "mismatch", an increase in mobility of labor does not necessarily result in lower levels of unemployment. Also in the US it was observed that workers migrate to high-wage-regions and increase there existing unemployment. And last but not least it might be possible that the mobility of skilled labor is particularly high, so that a "brain drain" would exacerbate regional difficulties. As far as skilled and unskilled labor complement each other in the production process, the leaving of skilled labor would also imply job losses for unskilled labor. Such a phenomenon can only, if at all, be avoided by a higher dispersion of the wage structure as long as the number of low-skilled (service) jobs is restricted. However, the presumed higher mobility of skilled labor is by no means consistently based on empirical facts. Obvious counter-examples are the migrations of foreign workers in the 1960s and the (temporary) employment of (unskilled) construction workers from Great Britain and Portugal in Germany in the 1990s.

In a recent study Puhani (1999) investigates the migratory response with respect to changes in unemployment and income on the basis of regional panel data provided by Eurostat for West Germany, France, and Italy. These econometric estimates suggest that internal and external migration respond to changes in unemployment, albeit insufficiently, whereas the effect resulting from income changes turned out to be insignificant. Simulation results show that about 30 percent at most of an increase in the number of unemployed are accommodated by a migratory response in Germany one and a half years after the shock. The corresponding estimates for France and Italy are much more lower, namely 8 percent and 4 percent, respectively. In the case of West Germany it takes at least four years until more than half of the effects of a shock causing unemployment are accommodated by migration. Therefore, at least in the short run, labor mobility cannot act as a sufficient adjustment mechanism to asymmetric shocks in EMU-countries. ${ }^{41}$ The same conclusion is reached by Burda (1999): "Indeed, the available evidence on labor mobility in the European context is remarkably discouraging and suggests that a major component of rigidity derives from labor's unwillingness to move" (p. 4).

With the flexible nominal exchange rate being abandoned as an adjustment instrument and with labor mobility being too low and/or to some extent problematic, capital mobility might 
play an important role in EMU. The underlying idea is that in the presence of a countryspecific shock, capital can be imported temporarily so that domestic investment is not restricted to domestic savings which are possibly already hit by the shock.

The relevance of this adjustment instrument obviously depends, among other preconditions, on the degree of international capital mobility. Given the empirical finding by Feldstein and Horioka (1980), who use the well-known domestic investment-saving correlations, of a surprisingly low degree of international capital mobility, ${ }^{42}$ the question arises whether capital mobility will be sufficiently high in EMU. In updating the Feldstein-Horiokaregression for, among other countries, "core-countries" (i.e., Deutsche Mark-zone countries Austria, Belgium, Denmark, France, West Germany, and the Netherlands), Stirböck and Heinemann (1999) conclude that the correlation weakened during 1965 to 1980, but strengthened again in the 1990 's, implying a relatively lower capital mobility in the latter time period. While this is bad news for EMU, the authors stress that capital mobility may increase within the EMU zone due to, for example, the loss of exchange rate volatility as a barrier for international capital mobility. This possibility may be an acceptable forecast, but capital mobility seems too unreliable a candidate as a substitute for nominal exchange rate adjustments.

The third possible substitution mechanism is relative price flexibility. A real depreciation may restore a country's competitiveness if it was hit by an adverse shock, i.e., the relative price of non-tradables has to fall in order to stimulate the production of tradables. ${ }^{43}$ Depending on labor's share in production this requires that wages, as remuneration of the immobile factor of production, have to react to a sufficient extent. But even if this is the case, there is ample evidence on price rigidities, at least in the short-run. As has been shown by Smolny (1998), especially in sectors with a large proportion of product innovators which is hopefully of growing importance in Germany -, price competition is reduced.

Fourth, financial transfers as a substitute for flexible wages may be suitable but are unwarranted for several reasons. Most importantly, financial transfers between states bear the risk of creating disincentives implementing an unpleasant policy in order to restore international competition. As has been shown by Büttner (1999), even in Germany where fiscal federalism is critized for its heavy equalization only about 17 percent of income

\footnotetext{
${ }^{41}$ Puhani (1999) also provides a summary of other related empirical studies.

${ }^{42}$ A short summary of the literature on the Feldstein-Horioka-hypothesis is offered in Stirböck and Heinemann (1999). The Feldstein-Horioka estimates are based on cross country regressions with the investment-GDP ratio as the dependent variable and the gross saving-GDP ratio as (one of) the explanatory variable(s).

${ }^{43}$ See Siebert (1998).
} 
variation across West Germany's states have been removed by fiscal flows during the past two decades. This is the more important the greater the extent of transfer payments is, which in turn depends on how asymmetric future shocks will be.

Taken together, the answer to the first question is that while in principle substitution mechanisms for wage flexibility exist, they are either of insufficient order of magnitude or unwarranted or both.

The second question deals with an analysis of the extent to which pre-EMU countries could rely on exchange rate adjustments in the past in order to smooth divergent developments within the pre-EMU area. This topic has been analyzed in a recent econometric study by Müller and Buscher (1999) for six countries (Austria, France, Germany, Italy, Netherlands, UK) and the sample period 1974 to 1996, i.e. the time after the final collapse of the Bretton Woods Monetary System. The authors run regression with a measure of economic synchronization between countries - namely bilateral differences of economic growth rates or unemployment rates, respectively - as the dependent variables and, among other variables, nominal or real exchange rates as the explanatory variables. Leaving aside important details of the study, its main findings are that for exchange rates, either in nominal or in real terms, no unique results could be obtained for all countries. Exchange rate policies, if present, showed different impact on the inter-country differences mentioned before, depending on the time period chosen as well as on the country under consideration. This conclusion does not necessarily come as a surprise since some countries, such as Austria and the Netherlands, fixed their nominal exchange rates vis-à-vis the Deutsche Mark at least since the mid-1980's, while others such as the UK pursued a more independent policy. Hence, changes in nominal exchange rates vis-à-vis the Deutsche Mark were quantitatively unimportant, if not insignificant for Austria and the Netherlands. But even for the UK the stabilizing impact of the nominal exchange rate vis-à-vis the Deutsche Mark with respect to growth rates and unemployment rates, respectively, was weak during the whole sample period. Italy is the only country which exhibits asymmetric-reinforcing tendencies of nominal exchange rate movements vis-à-vis the Deutsche Mark. However, this destabilizing influence relates only to labor market developments in contrast to growth differentials with shock absorbing effects. Taken together, the former instrument of the nominal exchange rate of the Deutsche Mark vis-à-vis major EMU currencies was hardly an important tool for adjusting divergent developments. Seen from this viewpoint, there is no reason for grieving over this loss. 
But this is, of course, not the end of the story. If nominal exchange rate mechanisms did not play a very important role as adjustment instruments in the past this does not suggest that also in the foreseeable future such an instrument might not have been helpful even if it had been at the disposal of economic policy, and that now there is urgent need for reliable substitutes. Whether this is a realistic view depends on the type of economic shock which may cause divergent economic developments between EMU-member states. This is the third question posed above. Put differently, what type of economic disturbance can basically be smoothened by exchange rate adjustment and how likely is the occurrence of such disturbances? If an exchange rate mechanism was to be of great help in the future then giving up this instrument would indeed call for a substitute like additional wage flexibility.

A useful distinction, frequently made in the literature is between symmetric and asymmetric shocks. Symmetric shocks are common in all countries, whereas asymmetric shocks concern some particular countries only and possibly hit each of them to a different extent. If EMUcountries are likely to be subject to symmetric shocks, then at first glance a substitute for the abandoned nominal exchange rates is not needed. As long as single countries undertake, however, efforts such as wage moderation, for example, which differ in their intensity and success, to counter the consequences of that shock, then divergent developments will be the consequence. Moreover, as has been emphasized by Blanchard and Katz (1992) for the U.S., a monetary union may induce a higher specialization of production. If this is so, this would increase the likelihood of asymmetric shocks. In the case of an asymmetric shock, for example a technology shock which hits a specific sector in a country, a depreciation of the currency of the respective country may help to buy some time in order to accommodate the shock by a specific sectoral economic policy. Such a policy would mean shouldering the burden on all economic agents suffering from a decrease in real incomes due to higher import prices as a consequence of the devaluation, namely labor via a fall in the real wage rate. ${ }^{44}$ However, given the high intra-sectoral integration within major EMU-countries, it is hard to think of any (sectoral) shocks which would only concern one or a few countries. Moreover, if the shock hits a sector producing primarily non-tradable goods and leads to a dismissal of workers there, it is unlikely that these unemployed are able to switch immediately to a sector which produces tradable goods and possibly benefits from the devaluation. Nevertheless, a depreciation may provide some time during which necessary adjustments to the shocks can be undertaken. Insofar this is a relevant scenario a nominal exchange rate mechanism would help, but it should be kept in mind that the country affected

\footnotetext{
${ }^{44}$ This reduction of the real wage rate, however, will for obvious reasons not lead to higher employment.
} 
cannot avoid sharing the real burden of the shock even if an exchange rate mechanism were at disposal.

This leaves us with the question of whether in EMU symmetric or asymmetric shocks are more likely. Past experience of present EMU member countries may help to provide some insight, and, indeed, several econometric studies are devoted to an assessment of the likely importance of both shocks. ${ }^{45}$ Although quite a few econometric studies have been undertaken, no consensus has emerged yet. For example, Artis and Zhang (1995) find a high degree of synchronous development in business cycles among former EMS-countries (using deviations from trend production in industries as a measure of business fluctuations). Gros (1996) estimates that for example sectoral and trade structures are fairly similar in France, Germany, and the Netherlands but that those of Finland, Greece, and Portugal are generally different from EU averages. This result is basically confirmed by Helg et al. (1995). The study by Karras (1996) analyzes European OECD countries for the time period from 1951 to 1990 and concludes that country-specific shocks were more important than common ones. In contrast to this result, Funke et al. (1999) show that the relevance of countryspecific shocks has decreased while world-wide shocks gained in importance.

In a more recent study, Buscher (1999) investigates business cycle relationships between EU-15, EU-11, and EU-core countries for the period from 1971 to 1997. Criteria for classifying a country as a core country are its EMS-membership and stable bilateral exchange rates over a longer time period. The study is partly based on cross correlations of per capita growth rates among countries as well as on Anova-techniques, allowing to break up the data variation into time-specific effects which are either common to all countries or country-specific. Three findings of this study are relevant for the present context. First, an inspection of cross correlation coefficients reveals that for nine out of eleven EMUcountries there is a significant contemporaneous correlation with the European EU-11 business cycle (where the contribution of each EMU-country has been removed from EU-11 GDP, of course), with the exception of Finland and Ireland. Second, with respect to convergence processes in Europe, estimating Barro-regressions for EU-15 countries and for the time period 1970 to 1997 , Buscher (1999) finds significance for unconditional $\beta$ -

\footnotetext{
${ }^{45}$ See the overview in Buti and Sapir (1998), pp. 158.
} 
convergence, albeit small values. In other words, the relative distance between a poor and a rich country - measured by per capita incomes - decreases by 0.8 percent per annum. ${ }^{46}$

Declining standard deviations of the log of per capita GDP ( $\sigma$-convergence) could be found in the early seventies as well as from 1985 onwards, while in the second time period $\sigma$ convergence with the exception of Luxemburg was stronger for the EMU-countries compared with all EU countries. Third, country-specific shocks turned out to be highly important for smaller countries such as Finland, Ireland, and Portugal with the exception of UK as a major country, although not yet an EMU-member country. On the other hand, countries such as Austria, France, West Germany, Italy, and Spain are - according to this study - dominated by common shocks.

Taken together, the answer to the third question is somewhat mixed. Tentative evidence suggests, however, that for major EMU-member countries common shocks are more likely than country-specific shocks without ruling out the latter. Departing from this there seems little justification for the claim that higher additional wage flexibility is urgently needed in order to replace the former exchange rate mechanism. Yet, wage policy should be on the lookout, since asymmetric shocks cannot be ruled out completely even for major EMUcountries.

This leaves us with the fourth question: What does this all mean for wage policy in Germany? It should be stressed again that the relevant question here is whether additional wage flexibility is called for as a consequence of EMU. It is another aspect that wage flexibility is required in order to contribute to a successful fight against unemployment. Moreover, the point here is not an assessment of the extent to which wage policy in Germany has met previous challenges resulting from adverse labor market developments or has even caused the latter. What is at stake here is whether wage policy must be aware of new challenges caused by monetary integration.

The answer is that for wage policy in Germany, the challenges due to EMU are less aggravating than it is sometimes claimed in the literature and in public discussion. Neither will competition as a consequence of EMU increase so substantially that additional wage flexibility on a large scale would be required, nor imposes the abolition of nominal exchange rates within EMU so urgent a need for a substitution mechanisms that, in the absence of other suitable instruments, wage policy has to serve as an overly important

46 The so-called Barro-regression regresses growth rates of real per capita GDP for all countries under consideration averaged over a given time period (e.g. 1970 to 1997) on the level of real per capita GDP of the base year of this time period (e.g. 1970). 
adjustment tool. Monumental paintings of horror scenarios on this matter can clearly be banished into the museum's store. Neither did Germany in the past use its nominal exchange rate as an adjustment instrument to a considerable extent, nor provides the nominal exchange rate mechanism a realistic chance to escape from the need to adjust. In fact, the opposite may be true: There is evidence that, on average, the nominal exchange rate volatility of the Deutsche Mark vis-à-vis major currencies of present EMU-countries resulted in losses of workplaces which actually had to be counterbalanced by wage moderation. ${ }^{47}$ This was the case during previous appreciations of the Deutsche Mark, that were not justified by real factors. This, however, can no longer happen.

While this seems good news for wage bargaining parties, there is no reason to sit back and take things easy. Asymmetric shocks cannot be ruled out for the future, and a flexible nominal exchange rate, if it were still at the country's disposal, could have been of some use in order to buy time for necessary adjustments. Similar arguments hold when other EMUcountries strengthen their efforts to increase their international competitiveness, for example by wage moderation. For these and similar scenarios wage policy in Germany must be on the lookout. But what is new about that. ${ }^{48}$ If EMU could become a catalyst for labor market reforms, however, it would have beneficial effects. ${ }^{49}$

\section{Conclusion}

At the turn of the millennium, wage policy in Germany has to face old and new challenges. Old challenges require wage moderation and a more flexible wage structure in order to contribute to a successful fight against persistently high levels of unemployment. Three leading potential causes of new challenges are reviewed in this study. In the order of declining importance these are skilled-biased technical progress, the increasing international integration of labor and product markets, and the monetary integration of the EMU. For all three cases, pertinent evidence was obtained by inspection of the past, but there are no signs that technological change and globalization will be confined to this century or even decade. The same argument holds for labor market effects of EMU.

What does this mean for future wage policy in Germany? Being still at the beginning of EMU the answer is relatively simple. While EMU in our opinion does not represent a major threat for wage policy, it should be on the lookout for possible country-specific shocks

\footnotetext{
${ }^{47}$ See Buscher and Müller (1999).

${ }^{48}$ See, for example, Gundlach and Nunnenkamp (1997).
} 
which are not extremely likely but cannot be ruled out for the future. Moreover, wage policy in Germany has to carefully watch wage policies in other (EMU) countries in order to remain competitive. From this viewpoint, a Europeanization of wage policy is inadequate.

Each country is responsible for achieving high levels of employment. With respect to wage policy, the growth trend of domestic labor productivity should serve as a guideline for increases in the (real) wage rate, however with a due discount to contribute to job creation. To carry out such a wage policy, no coordination is necessary.

Matters are much more difficult with respect to the impact of skill-biased technical change and globalization. There is every reason to argue that both trends will continue and, moreover, that nothing should be done to stop these forces, if that was possible at all, by wage policy (or other policy measures). Unfortunately, one has to recognize that we will not be able to help every unskilled unemployed worker with virtually no skills and/or motivation. Social policy shares some responsibility here as the last resort. On the other hand, there are quite a few unskilled unemployed who may be, to some extent, qualified by active labor market policies and, perhaps even more importantly, a promising policy consists in increasing the fraction of individuals who complete a vocational training. Wage policy can also contribute to help unskilled workers. As has been shown, a wage structure across skill groups that is more flexible downwards is able to create jobs mainly, albeit not exclusively, in the service sector. Reduction of wages at the bottom of the wage structure may also help to buy some time in order to undertake necessary measures to enable workers to find new workplaces in other sectors, especially in the presence of (severe) mismatch problems.

It goes without saying that claims for a more downward-flexibility of the wage structure does not mean to leave unskilled, low-paid workers to their fate. Whatever the merits of the US labor market, Germany should undertake every useful effort to avoid the problem of the "working poor". Although this should be done in a way which maintains sufficient incentives to search for work and accept job offers, even if low-paid, in the presence of a well-designed social safety net some disincentives will remain. To find a solution is fairly difficult and also more easily claimed than done effectively. Be that as it may, to provide support of the unskilled will no doubt impose a considerable financial burden on society, including those who are the definite winners of skill-biased technical progress and globalization.

\footnotetext{
${ }^{49}$ Gros and Hefeker (1999).
} 


\section{References}

Acemoglu, D. (1998), Why Do New Technologies Complement Skills? Directed Technical Change and Wage Inequality, Quarterly Journal of Economics 113:1055-1089.

Acemoglu, D. (1999), Patterns of Skill Premia, National Bureau of Economic Research, Working Paper No. 7018, Cambridge, Mass.

Artis, M. and W. Zhang (1995), International Business Cycles and the ERM: Is there a European Business Cycle?, Centre for Economic Policy Research, CEPR Discussion Paper Series No. 1191, London.

Autor, D.H., L.F. Katz, and A.B. Krueger (1998), Computing Inequality: Have Computers Changed the Labor Market?, Quarterly Journal of Economics 113:1169-1213.

Beißinger, T. and J. Möller (1999), Unemployment: Theoretical Explanations, Regensburger Diskussionsbeiträge Nr. 322 (June 1999), Regensburg.

Bellmann, L., S. Bender, and T. Schank (1999), Flexibilität der Arbeitsnachfrage: Substitutivität oder Komplementarität, Jahrbücher für Nationalökonomie und Statistik 219 (forthcoming).

Berman, E., J. Bound, and S. Machin (1998), Implications of Skill-Biased Technological Change: International Evidence, Quarterly Journal of Economics 113:1245-1279.

Black, S.W. (ed.) (1998), Globalization, Technological Change, and Labor Markets, Boston (Kluwer).

Blanchard, O.J. and L.F. Katz (1992), Regional Evolutions, Brookings Papers on Economic Activity 1:1992, 1-175.

Borjas, G., R.B. Freeman and L. Katz (1992), On the Labor Market Effects of Immigration and Trade, in: G. Borjas and R.B. Freeman (eds.), Immigration and the Work Force, Chicago (University of Chicago and NBER), 213-244.

Bound, J. and G. Johnson (1992), Changes in the Structure of Wages in the 1980's: An Evaluation of Alternative Explanations, American Economic Review 82:371-392.

Büttner, T. (1999), Regional Stabilization by Fiscal Flows and the Need for Fiscal Equalization in EMU, Zentrum für Europäische Wirtschaftsforschung (Centre for European Economic Research), ZEW Discussion Paper No. 99-23, Mannheim. 
Burda, M.C. (1998), Korreferat zum Referat B. Fitzenberger und W. Franz, in: B. Gahlen, H. Hesse, and H.J. Ramser (eds.), Verteilungsprobleme der Gegenwart. Diagnose und Therapie, Tübingen (Mohr Siebeck), 81-85.

Burda, M.C. (1999), European Labor Markets and the Euro: How Much Flexibility Do We Really Need?, mimeo, Humboldt-Universität zu Berlin, Berlin.

Buscher, H.S. (1999), Business Cycles in EU Member States, Zentrum für Europäische Wirtschaftsforschung (Centre for European Economic Research), ZEW Discussion Paper No. 99-16, Mannheim.

Buscher, H.S. and C. Müller (1999), Exchange Rate Volatility Effects on the German Labour Market: A Survey of Recent Results and Extensions, Forschungsinstitut zur Zukunft der Arbeit (Institute for the Study of Labor), IZA Discussion Paper No. 37, Bonn.

Buti, M. and Sapir, A. (1998), Economic Policy in EMU, Oxford (Clarendon Press).

Butler, A. and M. Dueker (1999), Does Foreign Innovation Affect Domestic Wage Inequality?, Journal of International Economics 47:61-89.

Caselli, F. (1999), Technological Revolutions, American Economic Review 89:78-102.

Chennells, L. and J. van Reenen (1999), Technical Change and the Structure of Employment and Wages: A Survey of the Micro-Econometric Evidence, mimeo.

Davis, D.R. (1998a), Does European Unemployment Prop Up American Wages? National Labor Markets and Global Trade, American Economic Review 88:478-494.

Davis, D.R. (1998b), Technology, Unemployment, and Relative Wages in a Global Economy, European Economic Review 42:1613-1633.

Dejonqueres, T., S. Machin, and J. van Reenen (1999), Another Nail in the Coffin? Or Can the Trade Based Explanation of Changing Skill Structures Be Resurrected?, Centre for Economic Performance, Discussion Paper No. 34, London.

Decressin, J. and A. Fatás (1995), Regional Labor Market Dynamics in Europe, European Economic Review 39:1627-1655.

DiNardo, J. and J.-S. Pischke (1997), The Returns to Computer Use Revisited: Have Pencils Changed the Wage Structure Too?, Quarterly Journal of Economics 112:291-303.

Eichengreen, B. (1990), One Money for Europe? Lessons from the US Currency Union, Economic Policy 10:117-187. 
Entorf, H., M. Gollac and F. Kramarz (1999), New Technologies, Wages, and Worker Selection, Journal of Labor Economics 17:464-491.

Falk, M. and B. Koebel (1999), Curvature Conditions and Substitution Pattern among Capital, Energy, Materials, and Heterogeneous Labour, Zentrum für Europäische Wirtschaftsforschung (Centre for European Economic Research), ZEW-Discussion Paper No. 99-06, Mannheim.

Falk, M. and K. Seim (1999), Workers' Skill Level and Information Technology. Evidence from German Service Firms, Zentrum für Europäische Wirtschaftsforschung (Centre for European Economic Reserach), ZEW Discussion Paper No. 99-14, Mannheim.

Feldstein, M.S. and C. Horioka (1980), Domestic Saving and International Capital Flows, Economic Journal 90:314-329.

Fitzenberger, B. (1997), Außenhandel, technischer Fortschritt und Arbeitsmarkt in Westdeutschland von 1975 bis 1990, Mitteilungen aus der Arbeitsmarkt- und Berufsforschung 30:642-651.

Fitzenberger, B. (1999a), Wages and Employment Across Skill Groups - An Analysis for West Germany, Berlin (Springer) (forthcoming).

Fitzenberger, B. (1999b), International Trade and the Skill Structure of Wages and Employment in West Germany, Jahrbücher für Nationalökonomie und Statistik 219:67-89.

Fitzenberger, B. and W. Franz (1998), Flexibilität der qualifikatorischen Lohnstruktur und Lastverteilung der Arbeitslosigkeit: Eine ökonometrische Analyse für Westdeutschland, in: B. Gahlen, H. Hesse and H.J. Ramser (eds.), Verteilungsprobleme der Gegenwart. Diagnose und Therapie, Tübingen (Mohr Siebeck), 47-79.

FitzRoy, F. and M. Funke (1996), Wages and International Price Competitiveness: Germany vs U.K., manuscript.

Freeman, R.B. (1995), Are Your Wages Set in Bejing?, Journal of Economic Perspectives 9:15-32.

Freeman, R.B. (1998), Divergent Performances: Job Creation and Income Determination in the EU and the U.S., in: German-American Academic Council Foundation (ed.), 
Labor Markets in the U.S.A. and Germany, Publications of the GAAC, Symposia, Vol. 5, Baden-Baden (Nomos), 51-80.

Freeman, R.B. and R. Schettkat (1999), The Role of Wage and Skill Differences in USGerman Employment Differences, Jahrbücher für Nationalökonomie und Statistik 219:48-66.

Funke, M., S. Hall, and R. Ruhwedel (1999), Shock Hunting: The Relative Importance of Industry-Specific, Region-Specific and Aggregate Shocks in the OECD Countries, The Manchester School of Economic and Social Studies (Supplement):49-65.

Gregg, P. and A. Manning (1997), Skill-Biased Change, Unemployment, and Wage Inequality, European Economic Review 41:1173-1200.

Gros, D. (1996), Towards Economic and Monetary Union: Problems and Prospects, Centre for European Policy Studies, CEPS Paper No. 65, Brussels.

Gros, D. and C. Hefeker (1999), Factor Mobility, European Integration and Unemployment, European Communities (ed.), EC/DGV-OECD/DEELSA Seminar: Wages and Employment, Luxemburg (Office for Official Publications of the European Communities), 125-146.

Gundlach, E. and P. Nunnenkamp (1997), Labor Markets in the Global Economy: How to Prevent Rising Wage Gaps and Unemployment, Institut für Weltwirtschaft an der Universität Kiel (Kiel Institute of World Economics), Kiel Discussion Papers No. 305, Kiel.

Haberler, G. (1961), A Survey of International Trade Theory, Princeton University, Princeton.

Haisken-DeNew, J.P. and K.F. Zimmermann (1995), Wage and Mobility Effects of Trade and Migration, University of Munich, Discussion Paper 95-24, Munich.

Haskel, J. (1999), Small Firms, Contracting-out, Computers and Wage Inequality: Evidence from UK Manufacturing, Economica 66:1-21.

Haskel, J. and M.J. Slaughter (1998), Does the Sector Bias of Skill-Biased Technical Change Explain Changing Wage Inequality, National Bureau of Economic Research, NBER Working Paper No. 6565, Cambridge (Mass.). 
Helg, R., P. Manasse, T. Monacelli, and R. Rovelli (1995), How Much (A) Symmetry in Europe? Evidence from Industrial Sectors, European Economic Review 39:10171041.

Hesse, H. (1996), Internationale Konkurrenz: Ursache von Arbeitslosigkeit und Lohnungleichheit?, in: B. Gahlen, H. Hesse and H.J. Ramser (eds.), Arbeitslosigkeit und Möglichkeiten ihrer Überwindung, Tübingen (Mohr Siebeck), 331-358.

Johnson, G.E. (1997), Changes in Earnings Inequality: The Role of Demand Shifts, Journal of Economic Perspectives 11:41-54.

Jones, R.W. (1965), The Structure of Simple General Equilibrium Models, Journal of Political Economy 73:557-572.

Kaiser, U. (1999), New Technologies and the Demand for Heterogenous Labor: Firm-level Evidence for the German Business-Related Services Sector, Zentrum für Europäische Wirtschaftsforschung (Centre for European Economic Research), ZEW Discussion Paper No. 99-07, Mannheim.

Karras, G. (1996), Is Europe an Optimum Currency Area? Evidence on the Magnitude and Asymmetry of Common and Country-Specific Shocks in 20 European Countries, Journal of Economic Integration 11:366-384.

Katz, L.F. and K.M. Murphy (1992), Changes in Relative Wages 1963-1987: Supply and Demand Factors, Quarterly Journal of Economics 107:35-78.

Klotz, S., F. Pfeiffer, and W. Pohlmeier (1999), Zur Wirkung des technischen Fortschritts auf die Qualifikationsstruktur der Beschäftigung und die Entlohnung, Jahrbücher für Nationalökonomie und Statistik 219:90-108.

Krueger, A.B. (1993), How Computers Have Changed the Wage Structure: Evidence from Micro Data, Quarterly Journal of Economics 108:33-60.

Krugman, P. (1995), Growing World Trade: Causes and Consequences, Brookings Papers on Economic Activity 1:1995, 327-377.

Landmann, O. and M. Pflüger (1996), Arbeitsmärkte im Spannungsfeld von Globalisierung und technologischem Wandel, in: B. Külp (ed.), Arbeitsmarkt und Arbeitslosigkeit, Freiburg (Haufe), 173-230.

Lawrence, R.Z. and M.J. Slaughter (1993), Trade and U.S. Wages: Giant Sucking Sound or Small Hiccup?, Brookings Papers on Economic Activity, Microeconomics, 161-226. 
Leamer, E. (1994), Trade, Wages, and Revolving Door Ideas, National Bureau of Economic Research, NBER Worker Paper No. 4716, Cambridge (Mass.).

Leamer, E.E. (1996), In Search of Stolper-Samuelson Effects on U.S. Wages, in: S. Collins (ed.), Imports, Exports, and the American Worker, Washington D.C. (Brookings Institution).

Leiner, N. and H.-J. Vosgerau (1998), Labor Mobility, Labor Standards, and Trade Policy: The Case of the German "Entsendegesetz", in: S.W. Black (ed.), Globalization, Technological Change, and Labor Markets, Boston (Kluwer), 113-135.

Lindbeck, A. and D.J. Snower (1996), Reorganization of Firms and Labor-Market Inequality, American Economic Review (Papers and Proceedings) 86:315-321.

Lloyd-Ellis, H. (1999), Endogenous Technological Change and Wage Inequality, American Economic Review 89:47-77.

Lücke, M. (1999), Sectoral Value Added Prices, TFP Growth, and the Low-skilled Wage in High-income Countries, Institut für Weltwirtschaft an der Universität Kiel (Kiel Institute of World Economics), Kiel Working Paper No. 923, Kiel.

Manacorda, M. and B. Petrongolo (1999), Skill Mismatch and Unemployment in OECD Countries, Economica 66:181-207.

Möller, J. (1999), Die Entwicklung der qualifikatorischen Lohn- und Beschäftigungsstruktur in Deutschland - Eine empirische Bestandsaufnahme, Jahrbücher für Nationalökonomie und Statistik 219 (forthcoming).

Mortensen, D.T. and C.A. Pissarides (1999), Unemployment Responses to "Skill-Biased" Technology Shocks: The Role of Labour Market Policy, Economic Journal 109:242265.

Müller, C. and H.S. Buscher (1999), The Impact of Monetary Instruments on Shock Absorption in EU-countries, Zentrum für Europäische Wirtschaftsforschung (Centre for European Economic Research), ZEW Discussion Paper No. 99-15, Mannheim.

Nickell, S. and B. Bell (1996), Changes in the Distribution of Wages and Unemployment in OECD Countries, American Economic Review (Papers and Proceedings) 86:302-308.

OECD (1997), Employment Outlook, Paris.

Paqué, K.-H. (1998), Internationaler Handel, technischer Fortschritt und Lohndifferenzierung. Ein Blick in die empirische Literatur, in: B. Gahlen, H. Hesse 
and H.J. Ramser (eds.), Verteilungsprobleme der Gegenwart. Diagnose und Therapie, Tübingen (Mohr Siebeck), 359-379.

Puhani, P.A. (1999), Labour Mobility - An Adjustment Mechanism in Euroland? Empirical Evidence for Western Germany, France, and Italy, Forschungsinstitut zur Zukunft der Arbeit (Institute for the Study of Labor), IZA Discussion Paper No. 34, Bonn.

Revenga, A.L. (1992), Exporting Jobs? The Impact of Import Competition on Employment and Wages in U.S. Manufacturing, Quarterly Journal of Economics 107:255-284.

Sachs, J.D. and H.J. Shatz (1994), Trade and Jobs in U.S. Manufacturing, Brookings Papers on Economic Activity 1:1994, 1-84.

Sauernheimer, K. (1996), Außenhandel, Reallöhne und Beschäftigung, Ordo 47:51-71.

Siebert, H. (1997), Labor Market Rigidities: At the Root of Unemployment in Europe, Journal of Economic Perspectives 11:37-54.

Siebert, H. (1998), The Euro: A Dozen Do's and Don't's, Institut für Weltwirtschaft an der Universität Kiel (Kiel Institute of World Economics), Kiel Discussion Paper No. 312, Kiel.

Siebert, H. (ed.) (1999), Globalization and Labor, Tübingen (Mohr Siebeck).

Slaughter, M.J. (1998), International Trade and Labour-Market Outcomes: Results, Questions, and Policy Options, Economic Journal 108:1452-1462.

Slaughter, M.J. and P. Swagel (1997), The Effect of Globalization on Wages in the Advanced Economies, International Monetary Fund, IMF Working Paper No. 43/97, Washington D.C..

Smolny, W. (1998), Innovations, Prices and Employment: A Theoretical Model and an Empirical Application for West German Manufacturing Firms, Journal of Industrial Economics 46:359-381.

Steiner, V. and R. Mohr (1998), Industrial Change, Stability of Relative Earnings, and Substitution of Unskilled Labor in West Germany, Zentrum für Europäische Wirtschaftsforschung (Centre for European Economic Research), ZEW Discussion Paper No. 98-22, Mannheim.

Steiner, V. and K. Wagner (1998), Relative Earnings and the Demand for Unskilled Labor in West German Manufacturing, in: S.W. Black (ed.), Globalization, Technological Change, and Labor Markets, Boston (Kluwer), 89-111. 
Stirböck, C. and F. Heinemann (1999), Capital Mobility within EMU, Zentrum für Europäische Wirtschaftsforschung (Centre for European Economic Research), ZEW Discussion Paper No. 99-19, Mannheim.

Topel, R.H. (1997), Factor Proportions and Relative Wages: The Supply-Side Determinants of Wage Inequality, Journal of Economic Perspectives 11:55-74.

Wood, A. (1994), North-South Trade, Employment and Inequality: Changing Fortunes in a Skill-Driven World, Oxford (Clarendon Press).

Wood, A. (1995), How Trade Hurt Unskilled Workers, Journal of Economic Perspectives 9:57-80.

Wood, A. (1998), Globalization and the Rise in Labour Market Inequalities, Economic Journal 108:1463-1482. 